\title{
Yeni Güvenlik Yaklaşımlarının Savunma Harcamaları Üzerine Etkileri: G-7, BRICS Ülkeleri ile Türkiye Üzerine Bir Değerlendirme
}

\section{The Effects on Defense Spending of New Security Approach: An Assessment on G-7, BRICS Countries with Turkey}

\section{Servet TAŞDELEN* ${ }^{*}$ Filiz GIRAY**}

$\ddot{O}_{z}$

Güvenlik çalışmaları, Soğuk Savaş sonrası dönemde uluslararası ilişkiler disiplini içerisinde en önemli konuların başında gelmektedir. Soğuk Savaş sonrası uluslararası güvenlik sisteminde meydana gelen güç dengesi değişimi, risk ve tehditlerin gerek öngörülememesi gerekse de artan bir şekilde devam etmesi, ülkelerin güvenliğe "Yeni Güvenlik Yaklaşımları" olarak adlandırılan farkl bir yaklaşımla bakmalarına neden olmuştur. Güvenlik anlayışındaki değişimin etkileyeceği alanların başında savunma harcamaları gelmektedir. Bu çalışmada güvenlik yaklaşımlarında meydana gelen bu farklllaşmanın ülkelerin savunma harcamalarına etkisi ve bu etkinin ne düzeyde gerçekleştiğinin araştırılması amaçlanmaktadır. Elde edilen bulgulara göre yeni güvenlik anlayışı çerçevesinde ülkelerin savunma harcamalarının yeterliliği değerlendirilebilecektir.

\footnotetext{
* Prj. Asist., Bursa Uludağ Üniversitesi, İktisadi ve İdari Bilimler Fakültesi, Maliye Bölümü, ORCID: 0000-0003-2543-6698, e-posta: servettasdelen@uludag.edu.tr.

${ }^{* *}$ Prof. Dr., Bursa Uludağ Üniversitesi, İktisadi ve İdari Bilimler Fakültesi, Maliye Bölümü, ORCID: 0000-0002-8765-8248, e-posta: giray@uludag.edu.tr.
}

Geliş Tarihi / Submitted : 26.02.2020

Kabul Tarihi / Accepted : 11.05.2020 
Güvenlik Stratejileri

Cilt: 16

Sayı: 34

Anahtar Kelimeler: Güvenlik, Yeni Güvenlik Yaklaşımları, Soğuk Savaş Sonrası Güvenlik, Ülke Örnekleri, Savunma Harcamaları.

\section{Abstract}

Security studies are one of the most important issues within the discipline of international relations in the post-Cold War period. The change in the balance of power in the post-Cold War international security system, both unpredictable and increasing of risks and threats, has led countries to look at security with a different approach called "New Security Approaches". The aim of this study is to investigate the effect of this differentiation in security approaches on the defense expenditures of countries and the level of this effect. According to the findings, the adequacy of the defense expenditures of the countries will be evaluated within the framework of the New Security Approach.

Keywords: Security, New Security Approaches, Post-Cold War Security, Security in BRICS Countries, Defense Expenditures.

\section{Giriş}

Uluslararası ilişkiler disiplininin en temel kavramlarından birisi de güvenliktir. Güvenlik, gerek kavramsal olarak gerekse teorik açıdan oldukça farklı perspektiflerle ele alınıp incelenmektedir. Özellikle küreselleşme sürecinin başlaması ve Soğuk Savaşın sona ermesiyle birlikte birçok alanda olduğu gibi güvenlik alanında da değişim ve dönüşüm yaşanmıştır. Soğuk Savaş Döneminin "Geleneksel/Klasik Güvenlik" anlayışının yansımaları olan Realizm, Neo-Realizm, Liberalizm ve Neo-Marksizm gibi güvenlik anlayışlarından, güvenliğin ekonomik, politik, sosyal, askeri ve çevresel boyutlarını ele alan ve "Yeni Güvenlik Yaklaşımları" olarak da ifade edilen çok boyutlu bir anlayışa geçilmiştir. Güvenlik anlayışında yaşanan bu çok boyutlu değişim, güvenlik sorunlarının bölgesel düzeyden çıkıp bölge dışı tüm ulusları ilgilendiren bir sorun haline getirmiştir. Zira günümüzde kolektif güvenliğe olan gereksinimin artması ve yaşanan sınır ötesi operasyonları bu durumun bir sonucu olarak da değerlendirmek mümkündür. 
Yeni Güvenlik Yaklaşımlarının Savunma Harcamaları Üzerine Etkileri:

G-7, BRICS Ülkeleri İle Türkiye Üzerine Bir Değerlendirme

Savunma harcamaları düzeyini belirleyen en önemli faktörlerden birisi de algılanan risk ve tehditlerin varlığıdır. Yani savunma harcamaları temelde güvende kalmak için yapılan harcamalardır. Güvenlik anlayışındaki değişim, savunma harcamaları üzerinde etkisinin olup olmadığını incelemek önem arz etmektedir. Bu nedenle Soğuk Savaş öncesi ve sonrası güvenlik yaklaşımları paralelinde

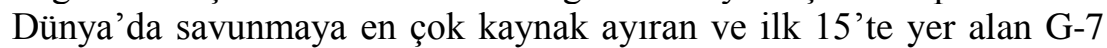
(Amerika Birleşik Devletleri (ABD), Almanya, Fransa, İngiltere, İtalya, Japonya, Kanada), BRICS (Brezilya, Rusya, Hindistan, Çin, Güney Afrika) ülkeleri ile Türkiye'nin savunma harcamaları bu çalışmada analiz edilecektir. Çalışma üç bölüm şeklinde organize edilmiştir. İlk bölümde, kavramsal çerçeve çizildikten sonra Soğuk Savaş sonrası dönemde yeni güvenlik anlayışındaki değişim ve dönüşüm ve yeni güvenlik yaklaşımları ele alınacaktır. İkinci bölümde, konu ile ilgili literatüre yer verilecektir. Üçüncü bölümde ise yeni güvenlik yaklaşımları bağlamında G-7, BRICS ülkeleri ile Türkiye'nin savunma harcamaları analiz edilecektir. Sonuç kısmında da analiz bulgularına dayalı olarak G-7, BRICS ülkeleri ile Türkiye'nin savunma harcamalarına yönelik durum tespiti yapılacaktır.

\section{Soğuk Savaş Sonrası Güvenlik Algılamalarında Değişim ve Dönüşüm: Yeni Güvenlik Anlayışı}

Güvenlik kavramına yönelik birçok tanımlama yapılmıştır. Uluslararası ilişkiler disiplininde güvenlik kavramını ilk ele alan Wolfers'e göre güvenlik; nesnel anlamda sahip olunan değerlere yönelik herhangi bir tehdidin yokluğu, öznel anlamda ise bu değerin saldırıya uğrayacağı korkunun olmaması halidir. ${ }^{1}$ Baldwin ise bu tanımı genişletmekte ve güvenliği, "sahip olunan değerlere karşı bir zararın en düşük olduğu durum" şeklinde tanımlamaktadır. ${ }^{2}$

\footnotetext{
${ }^{1}$ Arnold Wolfers, "National Security as an Ambiguous Symbol", Political Science Quarterly, 1952, Vol: 67, No: 4, 481-502, s. 484-485.

${ }_{2}$ David A. Baldwin, "The Concept Of Security", Review Of International Studies, 1997, Vol: 23, 5-26, p. 13.
}

275

Güvenlik Stratejileri

Cilt: 16

Say1: 34 
Brauch, güvenlik kavramının barış ile yakından ilgili olduğuna

Güvenlik Stratejileri

Cilt: 16

Sayı: 34 dikkat çekerek şöyle tanımlamaktadır. Güvenlik, "sosyal bilimlerde genel çerçeve ve boyutlara tekabül eden bireylere, konulara, toplumsal geleneklerle değişen tarihsel şartlara ve durumlara uyarlanan bir kavramdır". ${ }^{3}$ Bir tehlikeye yönelik tedbir alma ve savunma algısı üzerine kullanılan güvenlik kavramı, devletler açısından düşünüldüğünde ise devletlerin egemenliğini ve bütünlüğünü sağlama çabasıdır. ${ }^{4}$ Esas itibariyle güvenlik; coğrafi bölgelerin stratejik önemine göre bölge güvenliği, toplumun, devletin, uluslararası ve diğer grupların ve dolayısıyla bireyin güvenliği gibi birbirini etkileyen unsurları içermektedir. ${ }^{5}$ Güvenlik kavramı hangi bakış açısı ile ele alınırsa alınsın sosyal hayatın kozmopolit yapısıyla artan tehdit algisının farklılaşması ve aynı zamanda artmasıyla günümüzde olduğu gibi gelecekte de kavramın değişmesi ve gelişmesi devam edecektir.

Güvenlik kavramında olduğu gibi ülkelerin takip ettiği güvenlik anlayışı da değişim göstermiştir. Bu değişimi görebilmek için öncelikle Soğuk Savaş Döneminde geçerli olan geleneksel güvenlik anlayışına değinmekte büyük bir fayda vardır.

Geleneksel güvenlik anlayışı, devleti ve askeri güvenliği ön plana alan Realizm, Neo-Realizm, Liberalizm, Marksizm ve Neo-Marksizm gibi düşünce akımlarının etkisi altında şekillenmiş Soğuk Savaş Döneminin hakim güvenlik paradigmasıdır. Geleneksel güvenlik anlayışına göre güvenlik, devletlerarası rekabet ve çekişmelere dayanmakta ve askeri tehditler geleneksel güvenlik anlayışının temel konusu olmaktadır. Fiziksel güvenliğe vurgu yapan geleneksel güvenlik anlayışına göre, ulusal güvenliğin en belirgin unsuru ulusal sınırların diğer devletlerin

\footnotetext{
${ }^{3}$ Hans Günter Brauch, "Güvenliğin Yeniden Kavramsallaştırılması: Barış, Güvenlik, Kalkınma ve Çevre Kavramsal Dörtlüsü”, Uluslararası İlişkiler, 2008, Cilt:5, Sayı:18, $1-47$, s. 2.

${ }^{4}$ Beril Dedeoğlu, Uluslararası Güvenlik ve Strateji, Derin Yayınları, İstanbul, 2008, s. 24.

${ }^{5}$ Selahaddin Bakan ve Sonay Şahin, "Uluslararası Güvenlik Yaklaşımlarının Tarihsel Dönüşümü ve Yeni Tehditler", The Journal of International Lingual, Social and Educational Science, 2018, Cilt: 4, Say1: 2, 135-152, s. 136.
} 
Yeni Güvenlik Yaklaşımlarının Savunma Harcamaları Üzerine Etkileri:

G-7, BRICS Ülkeleri İle Türkiye Üzerine Bir Değerlendirme

saldırı ve tacizinden korunmasıdır. Kısacası geleneksel güvenlik anlayışı, askeri kuvvetlere ve ulusal sınırlara yönlendirilen tehditlere karşı önlem alınmasını öngören ve güvenliği Soğuk Savaş Döneminin genel karakteristik özellikleri bağlamında ele alan bir anlayıştır.

Soğuk Savaş Döneminin sona ermesi ve kutuplaşmaya dayalı sistemin çökmesiyle birlikte uluslararası sistemde bir istikrarsızlık ve kargaşa söz konusu olmuştur. Dönemin Amerikan Merkezi Haber Alma Teşkilatı (CIA) başkanı James Woolsy'da bu duruma dikkat çekerek, insanlık Sovyetler Birliği'nin uzun süren Soğuk Savaş yılları boyunca ne yapacağı konusunda rahatlıkla öngörüde bulunma olanağına sahipti. Oysa bu yeni uluslararası sistemde ilişkilerin çok daha karmaşık bir yapıya büründüğünü, mikro ölçekli çok sayıda tehlikenin varlığının söz konusu olduğunu ve bunların nasıl bir gelişme göstereceğini önceden kestirmenin olanaksız hale geldiğini belirtmiştir. ${ }^{6}$ Tehdit unsurlarındaki artışların meydana geldiği ve tehdit unsurlarının belli bir bölge ve coğrafya ile sınırlı kalmadığı yani tüm ülkeler için geçerli olduğu böylesi belirsiz bir dünyada, güvenlik anlayışında değişim ve dönüşüm kaçınılmaz hale gelmiştir.

Çalışmanın takip eden kısmında yeni güvenlik anlayışının teorik temellerinin oluşmasında önemli rolü olan Sosyal İnşacı, Eleştirel Yaklaşımlar, Galler Okulu ve Kopenhag Okulu açıklanıp, konuyla ilgili literatüre yer verilecektir.

\subsection{Geleneksel Güvenlikten "Yeni”ye Köprü: Sosyal İnşacı, Eleștirel Yaklaşımlar ve Galler Okulu}

Sosyal İnşacı Yaklaşım, sosyal olguların sürekli inşa halinde bulunduğu temel varsayımına dayanarak uluslararası toplumun güvenlik politikalarını nasıl dönüştürdügünü ve istikrarlı bir barış için koşulların nasıl sağlanabileceğini analiz etmekte ve toplumsal yapıya

\footnotetext{
${ }^{6}$ Tayyar Arı, Uluslararası Ilişskiler ve Dış Politika, Alfa Akademi Yayınları, Bursa, 2017, s. 174.

7 Kadir Sancak, "Güvenlik Kavramı Etrafındaki Tartışmalar ve Uluslararası Güvenliğin Dönüşümü”, Sosyal Bilimler Dergisi, 2013, Sayı: 6, 123-134, s. 129.
}

Güvenlik Stratejileri

Cilt: 16

Say1: 34 
ayrı bir önem atfetmektedir. ${ }^{8}$ Örneğin Sosyal İnşacı Yaklaşımın öne çıkan düşünürü Alexander Wendt ${ }^{9}$, geleneksel güvenlik anlayışı kapsamındaki ana akım yaklaşımlarda eksik olan güvenliğin sosyal boyutuna vurgu yaparak maddi unsurlar yerine fikirler, normlar, kültürler ve kimliklerden oluşan sosyal yapıyı analiz etmekte ve güvenliği bu çerçevede yorumlamaktadır. ${ }^{10}$ Ayrıca İnşacı Güvenlik Yaklaşımı, her ne kadar bireysel ya da toplumsal güvenliğe önem verse de temel aktör olarak devleti kabul etmektedir.

Gelenekselden yeni'ye geçişte bir diğer önemli yaklaşım Eleştirel Güvenlik Yaklaşımıdır. Eleştirel Güvenlik Yaklaşımı adından da anlaşılacağı üzere Realizmin ve Neo-Realizmin güç ve çıkarı merkeze alan görüşü eleştirip geleneksel (ana akım) güvenlik anlayışının politikalarına bir tepki olarak gelişmiştir.

Eleştirel Yaklaşımın fikri öncüleri, Frankfurt Okulundan farklı disiplinlerden bir araya gelen akademisyenlerden oluşmaktadır. Bunlar arasinda Max Horkheimer, Theodor W. Adorno, Friedrich Pollock, Walter Benjamin, Jürgen Habermas ve sonradan yaklaşımın gelişmesine katk1 sağlayan Robert Cox'1 göstermek mümkündür. ${ }^{11}$ Eleştirel teorisyenler, devletlerin farklı niteliklere sahip olmaları ve güvensizlik sorununun çözümünden ziyade sorunun bir parçası haline gelmeleri sebebiyle temel aktör olarak kabul edilmemesi gerektiğini savunmuşlardır. Yani devletler kendi halkları için güvenliği sağlayabilecekleri gibi aynı zamanda bir tehdit kaynağ 1 haline de gelebilirler. Bu nedenle, devlet

${ }^{8}$ Oktay Bingöl, "Yeni Güvenlik Yaklaşımları ve 21. Yüzyıl Güvenlik Sorunları", Hasret Çomak, Caner Sancaktar ve Sertif Demir, (ed.), Uluslararası Güvenlik Yeni Politikalar, Stratejiler ve Yaklaşımlar, Beta Yayınevi, İstanbul, 2016, 517-532, s. 21.

${ }^{9}$ Ayrıntılı bilgi için bkz. Alexander Went, Social Theory of International Politics, Cambridge University Press, Cambridge, 1992; Alexander Wendt, "Anarchy is What States Make of It: The Social Construction of Power Politics", International Organisation, 1992, Vol: 46, No: 2, 391-425.

10 Alexander Went, "Collective Identity Formation and the International State", American Political Science Review, 1994, Vol: 88, No: 2, 384-396, p. 385-387.

11 Bilgehan Emeklier, "Uluslararası İlişkiler Disiplininde Epistemolojik Paradigma Tartışmaları: Postpozitivist Kuramlar". Bilge Strateji, 2011, Cilt: 2, Sayı: 4, 139-184, s. 155. 
Yeni Güvenlik Yaklaşımlarının Savunma Harcamaları Üzerine Etkileri:

G-7, BRICS Ülkeleri İle Türkiye Üzerine Bir Değerlendirme

yerine bireye odaklanmalı ve bireyin özgürlüğü sağlanmalıdır. Devletin asli görevi ise bireyin özgürlügünü alıkoyan sosyal, fiziki, ekonomik ve siyasi alanlardaki kısıtlamaları ortadan kaldırmak olmalıdır. ${ }^{12}$

Eleștirel Yaklaşımın savunucularının Karl Marx'ın düșüncelerinden etkilenmeleri nedeniyle felsefi kökenlerinin Marksizm'e dayandığını söylemek yanlış olmayacaktır. ${ }^{13} \mathrm{Bu}$ nedenle eleştirel teorisyenler, ekonominin ve toplumun güvenlik sorunlarının kaynağı olarak kapitalizmi görmektedirler. Kapitalist ekonomik anlayışın neden olduğu gelir eşitsizliği ve ekonomik istikrarsızlık, eleştirel teorisyenler tarafindan ciddi bir şekilde eleştirilmektedir. $\mathrm{Bu}$ nedenle eleştirel teorisyenlerin birçoğu Dünya'da güvenliğin sağlanması için hakim olan kapitalist anlayışın değişmesi gerektiği görüşündedirler. ${ }^{14}$

Güvenlik anlayışının değişim ve dönüşümüne katkı sağlayan bir diğer ekol ise Galler Okuludur. Galler Okulu (Aberystwyth Okulu), Soğuk Savaş sonrası dönemde İngiltere'deki Aberyswyth Üniversitesi'nde Ken Booth, Richard Wyn Jones, Andrew Linklater, Keith Krause ve Michael Williams gibi akademisyenlerin de çalışmalarıyla tanınmaya başlanmıştır. Galler Okulunun entelektüel yönelimleri, Marksist Teori, İtalyan Marksist Gramsci ve Frankfurt Okulundan gelmektedir. Galler Okulunun öne çıkma nedenleri, Soğuk Savaş sonrası NATO'nun (North Atlantic Treaty Organization) başını çektiği Batı Bloğu ile SSCB (Sovyet Sosyalist Cumhuriyetler Birliği) Bloğu arasındaki jeopolitik ve stratejik rekabete dayalı güvenlik politikalarının önemini yitirmesiyle ortaya çıkan kimlik sorunları, ötekileştirme ve marjinalleşme gibi tehditlerdir. ${ }^{15}$ Galler Okulu, Soğuk Savaş sonrası dönemde farklılaşan tehditler nedeniyle bir yandan güvenlik anlayışını derinleştirirken

\footnotetext{
12 John Baylis, "Uluslararası İlişkilerde Güvenlik Kavramı", Uluslararası İlişkiler, 2008, Cilt: 5, Say1: 18, 69-87, p. 80-81

${ }^{13}$ Bilgehan Emeklier, a.g.m., 2011, s. 155.

${ }^{14}$ Bakan ve Şahin, a.g.m., 2018, s. 145.

${ }^{15}$ Fikret Birdişli, "Eleştirel Güvenlik Çalışmaları Kapsamında Frankfurt Okulu ve Soğuk Savaș Sonrası Güvenlik Sorunlarına Eleștirel Bir Yaklaşım: Galler Ekolü", Güvenlik Stratejileri, 2014, Cilt: 10, Sayı: 20, 229-256, s. 243-244.
}

Güvenlik Stratejileri

Cilt: 16

Say1: 34 
280

Güvenlik Stratejileri

Cilt: 16

Sayı: 34

(deepening security) öbür yandan güvenlik anlayışının genişletilmesini (broadening security) sağlamıştır. ${ }^{16}$

Galler Okulu'nun öncülerinden olan Ken Booth, güvenlik çalışmalarını özgürleşme ekseninde ele alarak, Realizmin entelektüel hegemonyası ile şekillenen geleneksel güvenlik anlayışını eleştirmektedir. $\mathrm{Bu}$ bağlamda güvenlik, Realist anlayıştaki gibi devletin temel aktör olduğu askeri güç ve düzen değil, ayn1 zamanda özgürleşmedir. $\mathrm{Bu}$ nedenle insanın özgür olması için tüm kısıtlamalar ortadan kaldırılmalıdır. Ayrıca Booth'a göre güvenlik, tehditlerin var olmamasıdır. Özgürleşme ise, bireylerin ve grupların serbestçe yapmak istediklerini seçmelerini engelleyen fiziki ve insani kisitlamalardan kurtarılmaları halidir. Booth, fiziki ve insani kısıtlamaları da savaş ve savaş tehdidi, yoksulluk, yetersiz eğitim, siyasi baskı şeklinde belirtmektedir. Özgürleşme ile güvenlik arasındaki bağlantıyı bir madalyonun iki yüzüne benzeten Booth, teorik olarak özgürlük ve güvenlik kavramlarının birbirlerini tamamladıklarını ifade etmektedir.

\subsection{Kopenhag Okulu}

Kopenhag Okulu, 1985 yllında Danimarka'da Kopenhag Üniversitesi'nin bünyesinde "Barış ve Çatışma Araştırma Merkezi” nin güvenlik üzerine yaptığı çalışmalar ile kurulmuştur. Bu merkezin kuruluş aşamasında özellikle askeri olmayan boyutlar ile Avrupa güvenliği üzerinde çalışılmıştır. Okul'un önde gelen teorisyenleri; Barry Buzan, Ole Waever ile Jaap de Wilde'dir. ${ }^{18} \mathrm{Bu}$ okula ismini ilk önce "Identity and Security: Buzan and the Copenhagen School" çalışması ile

\footnotetext{
${ }^{16}$ Ayrıntılı bilgi için bkz. Pınar Bilgin, "Güvenlik Çalışmalarında Yeni Açılımlar: Yeni Güvenlik Çalışmaları”, Stratejik Araştırmalar, 2010, Cilt: 8, Sayı: 14, s. 44.

17 Keen Booth, "Security and Emancipation, Review of International Studies", Cambridge University Press, 1991, Cilt: 17, Say1: 4, 313-326, p. 319.

${ }^{18}$ Jef Huysmans, "Revisiting Copenhagen: Or, On the Creative Development of a Security Studies Agenda in Europe", European Journal of International Relations, 1998, Vol: 4, No: 4, 479-505, p. 479-480.
} 
Yeni Güvenlik Yaklaşımlarının Savunma Harcamaları Üzerine Etkileri:

G-7, BRICS Ülkeleri İle Türkiye Üzerine Bir Değerlendirme

McSweeney vermiştir. ${ }^{19}$ Kopenhag Okulu, uluslararası güvenlik çalışmaları literatürüne üç alanda katkı sağlamıştır. Bunlar; Güvenlikleștirme/Güvenlik Dışılaştırma Teorisi, Sektörel Güvenlik Yaklaşımı ve Bölgesel Güvenlik Kompleksi Teorisidir. ${ }^{20}$

Kopenhag Okulu'nun güvenlik tehditlerinin içeriği ve ortaya çıkışı konusundaki tezlerinin izlerini güvenlikleştirme teorisinde bulmak mümkündür. Güvenlikleştirme teorisi, bir yandan geleneksel güvenlik anlayışındaki devlet merkezli salt askeri güç ilişkilerinin ötesinde olması gerektiğini savunurken öbür yandan bireylerin, sosyal grupların, ulusların, insanoğlunun varlığı ve refahına ilişkin her şeyin güvenlik tehdidi olarak ele alınmasını reddetmektedir. Bu yaklaşıma göre bir sorunun güvenlik tehdidi olabilmesi için öncelikle siyasi elitlerin söylem yoluyla siyasi alandaki bir konuyu güvenlik alanının dışına taşımaları ve buna karşı önlem almanın mümkün olması gerekmektedir. Kısacası güvenlik, bir söz-edim olarak görülmektedir ${ }^{21}$.

Kopenhag Okulu'nun güvenlik çalışmalarına en büyük katkısı toplumun güvenlik anlamında etkilendiği beş ana sektörün birbiriyle etkileşiminin "Güvenlikleştirme Teorisi"ne uygulanmasıdır. Bu bakımdan okulun öne çıkardığı temel husus, askeri tehditlerin toplumlar için tek güvensizlik kaynağı olmadığı, askeri tehditlerin yanı sıra sektörlerdeki güvenlik tehditlerinin de güvensizlik kaynağı oluşturmasıdır. $\mathrm{Bu}$ sektörler: Askeri güvenlik, siyasi güvenlik, ekonomik güvenlik, toplumsal güvenlik ve çevresel güvenliktir. Güvenliği sektör analizi temelinde incelemenin önemi, sektörler arasındaki özel ilişki tiplerini

\footnotetext{
${ }^{19}$ Ole Weawer, "Aberystyth, Paris, Copenhagen: New Schools in Security Theory and Their Origins Between Core and Periphery", http://www.scribd.com/doc/40010349/OleWaever-Aberystwyth-Paris-enNew-Schools-in-Security-Theory-and-Their-OriginsBetween-Core-andPeriphery. (Erişim Tarihi: 11.10.2019). 2004, p. 4.

${ }^{20}$ Başar Baysal ve Çağla Lüleci, "Kopenhag Okulu ve Güvenlikleştirme Teorisi", Güvenlik Stratejileri, 2011, 22: 61-96, s. 70.

${ }^{21}$ Sinem Açıkmeşe-Akgül, "Algı mı Söylem mi? Kopenhag Okulu ve Yeni-Klasik Gerçekçilikte Güvenlik Tehditleri”, Uluslararası İlişkiler, 2011, Cilt: 8, Sayı: 30, 4373, s. 57-59.
} 
282

Güvenlik Stratejileri

Cilt: 16

Sayı: 34

tanımlayıp birbirlerini nasıl etkilediklerini ortaya koymak ve bu şekilde bütüncül bir güvenlik bakış açısı sağlamaktır. ${ }^{22}$

Özellikle Eleştirel Yaklaşımın; kimin güvenliği, neyin güvenliği ve kimden/neden korunma gibi sorularıyla güvenliği sorgulamas1, Galler Okulu'nun özgürleşme güvenlik ilişkisi ve Kopenhag Okulu'nun güvenliği sektörel bazda incelemesi yeni güvenlik anlayışının özünü oluşturmaktadır. Bu bağlamda aşağıda yer alan Tablo 1, güvenliğin sağlanmasına yönelik sorulan sorulara cevap verilmesi ve günümüzdeki güvenlik yaklaşımlarının özetlenmesi bakımından büyük önem arz etmektedir.

Tablo 1: Genişletilmiş Güvenlik Kavramları ${ }^{23}$

\begin{tabular}{||l|l|l|l||}
\hline $\begin{array}{l}\text { Güvenlik } \\
\text { Kavramları }\end{array}$ & $\begin{array}{l}\text { Gösterilen } \\
\text { (Kimin } \\
\text { Güvenliği?) }\end{array}$ & $\begin{array}{l}\text { Risk Altındaki } \\
\text { Değer (Neyin } \\
\text { Güvenliği?) }\end{array}$ & $\begin{array}{l}\text { Tehdit } \\
\text { Kaynağı/Kaynakları } \\
\text { (Kimden/Neden } \\
\text { Korunma?) }\end{array}$ \\
\hline $\begin{array}{l}\text { Ulusal Güvenlik } \\
\text { [Siyasi, Askeri } \\
\text { Boyut] }\end{array}$ & Devlet & $\begin{array}{l}\text { Egemenlik, Toprak } \\
\text { Bütünlüğ̈̈ }\end{array}$ & $\begin{array}{l}\text { Diğer Devlet, Terörizm } \\
\text { (Devlet Dışı Aktörler) }\end{array}$ \\
\hline $\begin{array}{l}\text { Toplumsal } \\
\text { Güvenlik } \\
\text { [Boyutu] }\end{array}$ & $\begin{array}{l}\text { Milletler, } \\
\text { Toplumsal } \\
\text { Gruplar }\end{array}$ & $\begin{array}{l}\text { Ulusal Birlik, } \\
\text { Kimlik }\end{array}$ & $\begin{array}{l}\text { (Devletler) Milletler, } \\
\text { Göçmenler, Yabancı } \\
\text { Kültürler }\end{array}$ \\
\hline $\begin{array}{l}\text { Ekonomik } \\
\text { Güvenlik }\end{array}$ & $\begin{array}{l}\text { Bireyler } \\
\text { (Tüccarlar) }\end{array}$ & $\begin{array}{l}\text { Ticaret, Üretim, } \\
\text { Finans İlişkileri }\end{array}$ & $\begin{array}{l}\text { Devletler, Terörizm, } \\
\text { Küreselleşme }\end{array}$ \\
\hline İnsan Güvenliği & Bireyler, İnsanlık & $\begin{array}{l}\text { Beka, Hayat } \\
\text { Kalitesi }\end{array}$ & $\begin{array}{l}\text { Devlet, Küreselleşme, } \\
\text { Küresel Çevre Sorunları } \\
\text { (GEC), Doğa, Terörizm }\end{array}$ \\
\hline
\end{tabular}

${ }^{22}$ Barry Buzan, Ole Wæver ve Jaap De Wilde, Security: A New Framework for Analysis, Lynne Rienner Publishers, Londra, 1998, p. 7.

${ }^{23}$ Hans Günter Brauch, Ibid., p. 11. 
Yeni Güvenlik Yaklaşımlarının Savunma Harcamaları Üzerine Etkileri:

G-7, BRICS Ülkeleri İle Türkiye Üzerine Bir Değerlendirme

\begin{tabular}{|c|c|c|c|}
\hline $\begin{array}{l}\text { Çevresel } \\
\text { Güvenlik } \\
\text { [Boyutu] }\end{array}$ & Ekosistem & Sürdürülebilirlik & İnsanlık \\
\hline $\begin{array}{l}\text { Cinsiyet } \\
\text { Güvenliği }\end{array}$ & $\begin{array}{l}\text { Cinsiyet } \\
\text { İlişkileri, Yerli } \\
\text { Halk, Azınlıklar }\end{array}$ & $\begin{array}{l}\text { Eşitlik, Kimlik, } \\
\text { Dayanışma }\end{array}$ & $\begin{array}{l}\text { Ataerkillik, Totaliter / } \\
\text { Erktekelci Kurumlar } \\
\text { (Hükümetler, Dinler, } \\
\text { Elitler, Kültür), } \\
\text { Hoşgörüsüzlük }\end{array}$ \\
\hline
\end{tabular}

\section{3}

Güvenlik Stratejileri

Cilt: 16

Say1: 34

Tablo 1'de görüldüğü üzere, güvenlik kavramı; askeri güvenlik, siyasi güvenlik, toplumsal güvenlik, ekonomik güvenlik, insan güvenliği, çevresel güvenlik, kültür, kimlik ve cinsiyet güvenliği üzerinden sınıflandırılmıştır. ${ }^{24}$ Örneğin kültür ve kimlik, Soğuk Savaş sonrası dönemde güvenliğin bir aracı olarak görülmüştür. ${ }^{25}$ Güvenlik kavramının bu denli geniş tutulmasının ardından iki temel neden bulunmaktadır. Birincisi Soğuk Savaş sonrası dönemde risk ve tehditlerin öngörülememesinden ikincisi ise güvenliğin sadece devletin bekasıyla sağlanamayacağı düşüncesinden kaynaklanmaktadır. Bundan dolayı devletin bekasının yanı sıra bireyi de güvenliğin merkezine alan yeni güvenlik anlayışı, bireyin refahına etki eden her türlü risk ve tehlikenin güvenlikleştirilmesini amaçlamaktadır.

Kopenhag Okulu'nun üzerinde durduğu diğer bir önemli konu ise bölgesel güvenlik kompleksidir. Bu teori güvenliğin bölgesel dinamiklerini tekrarlayarak ön plana çıkartmayı hedeflemektedir. Buzan ve Waever'e göre, dünya çapında tüm devletler güvenlik anlamında birbirleriyle bağımlıdır. Herhangi bir devletin güvenliği kendisine sınır komşusu olsun veya olmasın diğer bir devletin güvenliğinden ayrı

\footnotetext{
${ }^{24}$ Ayrıntılı bilgi için bkz. Barry Buzan, People, States, and Fear: The National Security Problem in International Relations, Brighton, 1983.

${ }^{25}$ Elina Sopo, "Securitising Culture During the Cold War: The Geopolitical Aspect of Culture in European Discussions, 1949-1974", The International History Review, 2020, Vol: 42, No: 2, 391-409, p. 12.
} 
284

Güvenlik Stratejileri

Cilt: 16

Sayı: 34

düşünülemez. ${ }^{26}$ Örneğin kolektif bir savunma örgütü olan NATO, her ne kadar belli bir bölgeyi temsil etmek için kurulmuş olsa da bölgesel sınırları aşarak dünyanın birçok yerinde bölgesel güvenliği sağlamaya çalışmaktadır.

\section{2. İlgili Literatür}

Kollias ve Paleologou (2003), 1960-1998 dönemlerine ait verilerle Yunanistan'ın iç politika ve seçim değişkenleri ile dış güvenlik politikası kararlarının savunma harcamalarına etkisi ARDL sınır testi yaklaşımı kullanarak araştırmışlardır. Araştırmada Yunanistan'ın savunma harcamaları kısa vadede iç politika ve dış güvenlik faktörlerinden etkilendiği sonucuna varılmıştır. ${ }^{27}$ Rickli (2008) yaptığı çalışmada günümüzün kutupsuzlaşan dünyasında Avrupa'nın küçük devletlerinin Soğuk Savaş sonrası askeri politikalarındaki değişimi araştırmıştır. ${ }^{28}$ Ezeani ve Ezeibe (2011), savunma harcamaları ile ulusal güvenlik arasındaki ilişkiyi Nijerya üzerinde incelemişlerdir. Nijerya'da savunma harcamaları yıllık olarak artmasına rağmen güvenliğin sağlanamadığı, aksine güvensizlik seviyesinin arttı̆̆ gözlemlenmiştir. ${ }^{29}$ Zayıf ve Erkenekli (2015), 1994-2013 yılları arasındaki verilerden yararlanarak NATO üyesi ülkeler için regresyon analizi ile kültürel değerlerin savunma harcamalarına etkisini araştırmışlardır. Araştırma sonuçlarına göre; savunma harcamaları ile kültürel değerler arasında orta düzeyde

${ }^{26}$ Barry Buzan ve Ole Waever, Regions and Powers, Cambridge University Press, Cambridge, 2003, p. 46.

${ }^{27}$ Christos Kollias ve Suzanna Maria Paleologou, "Domestic Political And External Security Determinants Of The Demand For Greek Military Expenditure". Defence and Peace Economics, 2003, Vol: 14, No: 6, 437-445.

${ }^{28}$ Jean- Marc Rickli, "European Small States' Military Policies After the Cold War: From Territorial To Niche Strategies", Cambridge Review Of International Affairs, 2008, Vol: 21, No: 3, 307-325.

${ }^{29}$ Emmanuel O. Ezeani ve Ezeibe Christian C., "Defence Expenditure and National Security in Nigeria", Ozoemenam Mbachu \& Ahmed Aliyu Sokoto, (ed.), Nigerian Defence And Securty: Policies and Strategies, Medusa Academic Publishers Limited, Kaduna, 2011, 227-252. 
Yeni Güvenlik Yaklaşımlarının Savunma Harcamaları Üzerine Etkileri:

G-7, BRICS Ülkeleri İle Türkiye Üzerine Bir Değerlendirme

anlamlı bir ilişki bulunmuştur. ${ }^{30} \mathrm{Bu}$ bağlamda toplumsal ilişkilerde güvenlik kaygısının ortadan kalkması için kültürel değerlerin etkisi göz ardı edilmemelidir. Özellikle de NATO gibi güvenlik ortaklıklarda toplumsal farklılıklar güvenlik için büyük önem arz etmektedir.

Skogstad (2016) güvenlik politikalarının ya bir güvenlik kurumuna katılma ya da özel bir amaç için koalisyon kurmayı gerektirdiğini belirtmektedir. Soğuk Savaş sonrası dönemde ülkelerin savunma bütçelerini belirleyen unsurları 124 ülke için 16 yıllık verilerden yararlanarak Skogstad tarafından analiz edilmiştir. ${ }^{31}$ Waszkiewicz (2016), 1996-2014 dönemi verileri ile Türkiye ile Yunanistan'ın savunma harcamalarının artmasına neden olan siyasi, ekonomik ve askeri faktörleri Granger nedensellik testi ile analiz etmiştir. Analiz sonucuna göre; Yunanistan'da diş tehditler Türkiye'de ise hem iç tehditler hem de dış tehditler ulusal güvenlikte önemli rol oynamaktadır. Ayrıca çalışmada Yunanistan'ın savunma harcamalarının artmasının temel nedeni ekonomik faktörler, güvenlik taleplerinin artması ve Türkiye ile sınır sorununun varlığı gösterilmektedir. Türkiye'nin savunma harcamasına neden olan faktörlerin başında ise ekonomik faktörlerden ziyade siyasi faktörler ve milli güvenlik faktörü yer almaktadır. Regresyon analizi sonucunda savunma bütçeleri ile mekânsallık arasında pozitif bir ilişki olduğu sonucuna ulaşılmıştır. ${ }^{32}$ Sopo (2020) ise yaptığı çalışmada 1950'lerin başından itibaren Avrupa Birliği Enstitüsü politikacılarının bir güvenlik ve hayatta kalma sorunu olarak gittikçe artan şekilde kültürü tanımlamasını tartışmıştır. ${ }^{33}$

\footnotetext{
${ }^{30}$ Vedat Zayıf ve Memed Erkenekli, "Kültürel Değerlerin Savunma Harcamalarına Yansıması: NATO Ülkeleri Arasında Bir Uygulama", Savunma Bilimleri Dergisi, 2015, Cilt: 14, Say1: 2, 1-43.

${ }^{31}$ Karl Skogstad, "Defence Budgets In the Post-Cold War Era: A Spatial Econometrics Approach", Defence and Peace Economics, 2016, Vol: 27, No: 3, 323-352.

32 Grzegorz Waszkiewicz, "Drivers Of Greek And Turkish Defense Spending", International Journal of Management and Economics, 2016, Vol: 51, No: 1, 33-46.

${ }^{33}$ Elina Sopo, Ibid., p. 1-13.
}

\section{5}

Güvenlik Stratejileri

Cilt: 16

Say1: 34 
286

Güvenlik Stratejileri

Cilt: 16

Sayı: 34

3. Yeni Güvenlik Yaklaşımlarının G-7, BRICS Ülkeleri ile Türkiye'nin Savunma Harcamalarına Etkilerinin Analizi

Soğuk Savaş sonrası dönemde, asimetrik tehditlerin yaşanmaya başlanmasıyla birlikte ülkeler, savunma planlamalarında politika değişimine gitmek zorunda kalmışlardır. Ülkelerin savunma planlamaları değişimi, "Tehdide Dayalı Planlama"dan (Soğuk Savaş döneminde), "Yeteneğe Dayalı Planlama" (Soğuk Savaş sonrasında) ve "Yetenek Tabanlı Planlama" ya (11 Eylül 2001 sonrasında) şeklinde gerçekleşmiştir. ${ }^{34} \mathrm{Bu}$ bağlamda günümüzde hem G-7, BRICS ülkelerinin hem de Türkiye'nin savunma planlama anlayışı, Kopenhag Okulu'nun sektörel güvenlik kapsamındaki tüm faktörleri hesaba katan "Yetenek Tabanlı Planlama" anlayışı kapsamında hazırlanmaktadır. Söz konusu ülkelerin savunma planlamalarının bu şekilde hazırlanması savunma harcamalarının düzeyine de etki etmektedir.

Ülkelerin savunma bütçeleri hazırlamalarında belirleyici olan faktörleri yansıtan yaklaşımlar da Savaş Öncesi ve Sonrası Dönemlerde değişim göstermiştir. Bu yaklaşımlar, "Dışsal Yaklaşım (External Approach)" ve "İçsel Yaklaşım (Internal Approach)" olmak üzere ikiye ayrılmaktadır. Bir ülkenin savunma bütçesinin, rakibinin bütçesinin bir fonksiyonu olduğu model Dışsal Yaklaşım olarak adlandırılır. Richardson'un Eylem-Reaksiyon Teorisi olarak da bilinmektedir. Bu yaklaşımda, bir ülkenin savunma bütçesinin öncelikle belirleyicisi ülkenin sınırları dışından kaynaklanmaktadır. İçsel Yaklaşım da ise savunma bütçesinin oluşturulmasında politik ve ekonomik unsurlar üzerinde odaklanılmaktadır. Bu yaklaşım, harcama düzeyi ve diğer ulusların savunma harcamalarından ziyade bürokrat ve politikacıların yüzleştikleri teşviklere dayanır. ${ }^{35}$ Örneğin Cusack ve Ward (1981), seçim, toplam talep dalgalanmaları ve genel ekonomik performansın

\footnotetext{
${ }^{34}$ Mustafa Kemal Topçu, "Savunma Planlamasının Ekonomiye Etkileri ve Savunma Bütçeleri”, Savunma Bilimleri Dergisi, 2010, Cilt: 9, Say1: 1, 75-96, s. 77-78.

${ }^{35}$ Karl Skogstad, Ibid., p. 323-324.
} 
Yeni Güvenlik Yaklaşımlarının Savunma Harcamaları Üzerine Etkileri:

G-7, BRICS Ülkeleri İle Türkiye Üzerine Bir Değerlendirme

dışsal faktörlerden üstün olduğunu belirterek İçsel Yaklaşımlar üzerinde durmuşlardır. ${ }^{36}$

Savunma harcamaları belirlenirken Soğuk Savaş öncesi dönemde İçsel Yaklaşım daha güçlü olmasına rağmen Soğuk Savaş sonrası dönemde Dışsal Yaklaşımın daha önemli rol oynadığı ileri sürülmektedir. Diğer bir ifadeyle İçsel Yaklaşım potansiyel role sahiptir. Ancak Soğuk Savaş sonrası döneme ilişkin analizler göstermiştir ki, Dışsal Yaklaşım savunma harcamalarının önemli bir belirleyicisidir. Çünkü Soğuk Savaş sonrası dönemde uluslararası ilişkilerde iki zıt kutuplaşma artık olmadığından ülkeler için daha değişken olabilmektedir. Ekonomik büyüme bölgesel gücün ortaya çıkmasına yol açabilmektedir. Ülkeler daha fazla ülkenin savunma harcamasını dikkate almak durumundadırlar. Ayrıca İçsel Yaklaşım ülkeler açısından kontrol edilebilir. ${ }^{37}$ Pamp ve Thurner (2017), Richardson yaklaşımının Soğuk Savaşın ağırlığında askeri harcamalardaki hızlı artışı açıklamak niyetiyle geliştirilmiş olduğunu ileri sürmüşlerdir. ${ }^{38}$ Askeri kuvvet, ekonomik güçle aynı derecede olmaması halinde sürdürülmesi zordur. ${ }^{39}$ Bu konuda yapılan ampirik çalışmalarda da benzer sonuçlar elde edilmiştir. Örneğin Wyner ve Xie (1997) Çin'de 1960-1989 dönemi için Richardson yaklaşımının yani Dışsal Yaklaşımın geçerliliğini araştırdıkları bir çalışma yapmışlardır. Çalışma sonucuna göre Çin'deki askeri harcama düzeyindeki gelişimin Dışsal Yaklaşımla açıklanmadığı belirtilmektedir. ${ }^{40}$ Yine Bromund

\footnotetext{
${ }^{36}$ Thomas R. Cusack ve Michael Don Ward, "Military Spending İn The United States, Soviet Union, And The People's Republic Of China", Journal of Conflict Resolution, 1981, Vol: 25, No: 3, 429-469.

${ }^{37}$ Karl Skogstad, Ibid., p.325.

${ }^{38}$ Oliver Pamp ve Paul W. Thurner, "Trading Arms and The Demand For Military Expenditures: Empirical Explorations Using New SIPRI-Data". Defence and Peace Economics, 2017, Vol: 28, No: 4, 457-472.

${ }^{39}$ Sandra Krtalić ve Aleksandar Major, "Military Expenditures in the Maelstrom of the Globalized World" Economic Research-Ekonomska Istraživanja, 2010, Vol: 23, No: 2, 142-161, p. 142.

${ }^{40}$ Brittani Wyner ve Ligun Xie, "Modeling China's Military Expenditures as an Action-Reaction Process: A Preliminary Study", Journal of Chinese Political Science, 1997, Vol: 3, No: 2, 47-70.
}

287

Güvenlik Stratejileri

Cilt: 16

Say1: 34 
288

Güvenlik Stratejileri

Cilt: 16

Sayı: 34

(2009) günümüz demokrasilerinde savunma harcamalarının bir ekonomik sorun olmadığı, güvenlik sorunu olduğunu belirtmektedir. ${ }^{41}$

Çalışma metodolojik olarak G-7, BRICS ülkeleri ile Türkiye'nin savunma harcamalarının yıllar itibariyle gelişimi ve savunma harcamalarının GSYH içindeki payını gösteren veriler yardımıyla gelişen güvenlik çerçevesinde analiz edilmesi amaçlanmaktadır. G-7 ülkeleri; Almanya, ABD, Birleşik Krallık, Fransa, İtalya, Japonya ve Kanada'dan oluşmaktadır. Bu ülkeler küresel gelirin yaklaşık \% 65 'ine sahip ekonomileri ile gelişmiş ülke gruplarını temsil etmektedirler. BRICS üyesi ülkeler ise Brezilya, Rusya, Hindistan, Çin ve Güney Afrika Cumhuriyetidir. Dünya ekonomisinin yaklaşık beşte birini oluşturan bu ülkelerin temel özelliği hızlı büyüyen ekonomilere sahip olmalarıdır. Gerek G-7 ülkeleri gerekse BRICS ülkeleri ekonomik güçlerinin bir yansıması olarak güvenlik sistemleri açısından da önem arz eden ülkelerdir.

Çalışmada kullanılan veriler SIPRI (Stokholm Uluslararası Barış Araştırma Enstitüsü -Stockholm International Peace Research Institute) ve WMEAT (Dünya Askeri Harcamaları ve Silah Transferleri - World Military Expenditures and Arms Transfers) raporlarından alınmıştır.

G-7, BRICS ülkeleri ile Türkiye'nin savunma harcamaları gelişen güvenlik çerçevesinde analiz edilecektir. Bundan dolayı da konunun anlaşıla bilirliği açısından yapılacak analizler, Soğuk Savaş dönemi ve sonrası dönem şeklinde iki alt başlıkta değerlendirilecektir.

\subsection{Soğuk Savaş Döneminde Savunma Harcamalarının Seyri}

II. Dünya Savaşı'ndan sonra ABD'nin özgür dünyanın savunmasını üstlenmesi buna karşın SSCB'nin de, üçüncü dünya ülkelerinin emperyalist devletlere karşı yürüttükleri bağımsızlık mücadelesinden yararlanarak siyasi ve ekonomik alanda kendi hegemonyasını kurmak istemesi iki blok arasında Soğuk Savaşa neden olmuştur. Yaşanan

${ }^{41}$ Ted R. Bromund, "Demystifying Defense: Exposing Myths about US Military Expenditures", Harvard International Review, 2009, Vol: 31, No: 1, 36-40. 
Yeni Güvenlik Yaklaşımlarının Savunma Harcamaları Üzerine Etkileri:

G-7, BRICS Ülkeleri İle Türkiye Üzerine Bir Değerlendirme

Soğuk Savaş Döneminde dünyanın iki kutuplu bir hale gelmesi risk ve tehditleri de artırmıştır. Bu gelişmelerle ilintili olarak iki blok arasında yaşanan silahlanma yarışı ve rekabete dayalı savunma sanayilerinin gelişimi olmuştur.

Soğuk Savaş Döneminin en belirgin bir diğer özelliği de ABD önderliğinde NATO'nun yeterli kuvvete sahip olmasının amaçlanmasıdır. Geleneksel güvenlik anlayışının hakim olduğu Soğuk Savaş Döneminde belirsizliğin az olması, düşmanın ve gücünün belli olması ve ülkelerin de düşmanın gücünden daha fazlasına sahip olma isteği ülkelerin savunma harcamalarının belirleyicisi olmuştur. ${ }^{42}$

$\mathrm{Bu}$ çalışmada esas alınan G-7, BRICS ülkeleri ve Türkiye'de tarihsel süreç içerisinde yaşanan problemler, risk ve tehditlerin varlığı, coğrafi konumlar, komşu ülkelerin savunma harcamaları düzeyi, siyasal rejimler ve ülkelerin ekonomik durumları savunma harcamaları düzeyini belirleyen faktörler arasında yer almaktadır. Tüm bu faktörler bağlamında 1971-1989 yılları arası G-7, BRICS ülkeleri ve Türkiye'nin savunma harcamalarının seyri Tablo 2'de gösterilmektedir.

Tablo 2: Seçilmiş Bazı G-7, BRICS Ülkeleri İle Türkiye'nin Savunma Harcamalarının Seyri (1971-1989, Milyar \$) ${ }^{43}$

\begin{tabular}{|c|c|c|c|c|c|c|c||}
\hline Yıllar & ABD & İngiltere & Japonya & SSCB & Çin & Hindistan & Türkiye \\
\hline $1971 *$ & 128,054 & 16,963 & 5,438 & 140,948 & 36,776 & 3,731 & 2,093 \\
\hline 1972 & 127,547 & 18,202 & 6,196 & 147,032 & 38,606 & 3,630 & 2,111 \\
\hline 1973 & 121,767 & 18,386 & 6,533 & 153,067 & 38,849 & 3,111 & 2,116 \\
\hline 1974 & 121,969 & 18,917 & 6,356 & 160,011 & 39,754 & 3,327 & 2,140 \\
\hline 1975 & 117,856 & 18,479 & 7,108 & 165,999 & 40,819 & 4,024 & 3,515 \\
\hline
\end{tabular}

${ }^{42}$ Çağdaş Akif Kahraman, "Tarihsel Süreçte Savunma Planlaması Yaklaşımları İle Savunma Tedarik Sistemleri Arasındaki İlişki”, Kara Harp Okulu Bilim Dergisi, 2016, Cilt: 26, Say1: 2, 101-126, s. 106.

${ }^{43}$ WMEAT, World Military Expenditures and Arms Transfers, 1964-1990, https://www.state.gov/t/avc/rls/rpt/wmeat/_ (Erişim Tarihi: 18.09.2019).

289

Güvenlik Stratejileri

Cilt: 16

Say1: 34 


\section{0}

Güvenlik Stratejileri

Cilt: 16

Sayı: 34

\begin{tabular}{||c|c|c|c|c|c|c|c||}
\hline 1976 & 112,218 & 19,162 & 7,670 & 173,974 & 40,072 & 3,905 & 4,061 \\
\hline 1977 & 117,359 & 18,717 & 8,122 & 176,984 & 40,118 & 3,853 & 4,111 \\
\hline 1978 & 117,707 & 18,981 & 8,789 & 179,998 & 41,822 & 4,141 & 3,862 \\
\hline 1979 & 122,279 & 19,169 & 9,557 & 183,000 & 44,500 & 4,155 & 3,155 \\
\hline $1980 * *$ & 212,100 & 32,530 & 18,170 & 292,000 & 24,120 & 5,316 & 2,409 \\
\hline 1981 & 228,400 & 30,730 & 18,950 & 295,200 & 23,640 & 5,795 & 2,615 \\
\hline 1982 & 248,000 & 30,730 & 20,040 & 300,500 & 23,780 & 6,431 & 2,924 \\
\hline 1983 & 265,100 & 35,600 & 21,190 & 304,900 & 23,220 & 6,911 & 2,818 \\
\hline 1984 & 277,900 & 36,100 & 22,300 & 309,200 & 22,600 & 7,353 & 2,722 \\
\hline 1985 & 302,600 & 37,070 & 23,510 & 315,600 & 22,600 & 7,584 & 2,906 \\
\hline 1986 & 311,700 & 36,380 & 24,610 & 310,920 & 21,970 & 8,103 & 3,340 \\
\hline 1987 & 309,900 & 35,840 & 25,940 & 325,900 & 22,030 & 8,900 & 3,205 \\
\hline 1988 & 305,100 & 34,050 & 27,170 & 330,900 & 22,720 & 8,721 & 2,942 \\
\hline 1989 & 304,100 & 34,630 & 28,410 & 311,000 & 22,330 & 8,174 & 3,150 \\
\hline
\end{tabular}

* 1971-1979 arası yıllar 1979 sabit fiyatlarına göre düzenlenmiştir.

** 1980-1989 arası yıllar 1989 sabit fiyatlarına göre düzenlenmiştir.

1960'larda Dünya'da tahmin edilen savunma harcamalarının \% 97'si 36 ülkede toplanmıştır. Bu toplamın \% 84'ü ABD ve SSCB'ye aittir. ${ }^{44}$ Aynı şekilde Soğuk Savaş Döneminin iki süper gücü olan ABD ile SSCB 1971-1989 yılları arası savunma harcamaları en yüksek olan iki ülkedir. Bunun en önemli nedeni de her iki süper gücün belirgin olan tehdide karşı planlamalar yapmaları ve savunma sanayilerini güçlendirmelerinden kaynaklanmaktadır.

1971-1989 dönemi itibariyle Çin dışındaki ülkelerde artış olduğu görülmektedir. Bu dönemde diğer ülkelerde yıllar arasında dalgalanmalar bulunmaktadır. Soğuk Savaş Döneminde Türkiye'deki savunma harcamaları düzeyi ise nispi olarak düşüktür.

${ }^{44}$ Emile Benoit, Harold Lubell ve Sylvia Schuman, "World Defense Expenditures", Journal of Peace Research, 1966, Vol: 3, No: 2, 97-113. 
Yeni Güvenlik Yaklaşımlarının Savunma Harcamaları Üzerine Etkileri:

G-7, BRICS Ülkeleri İle Türkiye Üzerine Bir Değerlendirme

Ülkelerin savunma harcamalarına dolayısıyla güvenliğe verilen önemin temel göstergelerinden biri, savunma harcamalarının GSYH içindeki payıdır. Soğuk Savaş Döneminde G-7, BRICS ülkeleri ve Türkiye için savunma harcamalarının GSYH içindeki payı Tablo 3'te yer almaktadır.

Söz konusu ülkelerin devlet bütçesinden savunma harcamalarına ayırdıkları pay yıllar itibariyle mutlak değer olarak artmasına rağmen bu harcamaların GSYH içindeki payı iki ülke (G. Afrika ve Türkiye) dışında Tablo 3'te de görüldüğü üzere düşmüştür. Özellikle başta Rusya olmak üzere İngiltere, Fransa, Almanya, Japonya ve Brezilya'nın da savunma harcamalarında ciddi düşüşler yaşanmıştır.

Soğuk Savaş Döneminde ABD ile SSCB arasındaki güç ve nüfuz mücadelesi Kuzeydoğu Asya'da da etkisini göstermiştir. Kore Savaşı'ndan sonra ABD’nin öncülügünndeki Japonya, Güney Kore ve Tayvan ittifakı ile SSCB, Çin ve Kuzey Kore ittifakı arasındaki güç dengesi daha belirgin hale gelmiştir. Özellikle ABD'nin, Çin ile Tayvan arasındaki sınır sorunu nedeniyle Tayvan'a silah satışında bulunması ve Tayvan ile askeri ilişkiler geliştirmesi Çin'i rahatsız etmiştir. ${ }^{45}$ Nitekim Çin'in yaşadığ güvenlik sorunları ülkenin savunma bütçesine de yansımıştır. Örneğin Çin'in savunma harcamalarının GSYH içindeki payı 1960 yılında \% 9,5 iken, 1970'de 13,5'a yükselmiştir. Ancak sonraki y1llarda ise düşerek 1990'da \% 3,7 olmuştur (Tablo 3).

G-7 ülkeleri içinde GSYH içinde savunma harcamalarının payı en fazla olan ülke ABD'dir. BRICS ülkeleri içinde de SSCB en yüksek orana sahip ülke konumunda olmuştur. Gerek ABD'yi gerekse de SSCB'yi 1985'e kadar Çin takip etmiştir. Türkiye'de GSYH içinde savunma harcamalarının payı ise düşmeyip aynı seyirde (1975 yılı hariç) devam etmiştir. Bu durumda Türkiye'nin gerek coğrafi konumu gerekse belirli tehditlere maruz kalma olasılığının payı bulunmaktadır.

\footnotetext{
${ }^{45}$ Emine Akçadağ Alagöz, "Kuzeydoğu Asya'nın Değișen Güvenlik Ortamı”, Hasret Comak, Caner Sancaktar ve Sertif Demir, (ed.), Uluslararası Güvenlik Yeni Politikalar, Stratejiler ve Yaklaşımlar, 2016, Beta Yayınevi, İstanbul, 517-532, s. 517.
} 
292

Güvenlik Stratejileri

Cilt: 16

Sayı: 34

Türkiye'nin gerek Ege sorunu nedeniyle Yunanistan ile yaşadığı problemler gerekse de Doğu ve Güney Doğu bölgelerinde iç güvenlikten kaynaklı yaşanan sıkıntılar, özelikle 1970'li yılların başında Hava Kuvvetlerini Güçlendirme Vakfi, Deniz Kuvvetlerini Güçlendirme Vakfı ve Kara Kuvvetlerini Güçlendirme Vakfı'nın kurulması nedenleriyle Türkiye'nin savunma harcamalarının artarak devam etmesine neden olmuştur. Ayrıca 1974 yılında Kıbrıs Barış Harekatının başlaması ve ABD tarafından Türkiye'ye uygulanan silah ambargosu ASELSAN'nın kurulmasını zorunlu kılmış bu durum Türkiye'nin savunma harcamalarının artmasının bir diğer nedeni olmuştur. ${ }^{46}$

1980'li yıllar da yine Türkiye'nin savunma harcamaları açısından son derece önemlidir. 1980'lerin başında Türk Silahlı Kuvvetleri'nin modernizasyonu programı başlatılmıştır. Bu programın temel amacı, silah donanımını yenilemek ve bunu da ulusal silah sanayini kurarak gerçekleştirmektir. Modernizasyon programının finansmanının önemli bir kısmı ise bütçe dışından, Savunma Sanayii Destekleme Fonundan karşılanmıştır. ${ }^{47}$

${ }^{46}$ Ayrıntılı bilgi için bkz. Şennur Sezgin ve Selami Sezgin, "Dünya'da ve Türkiye'de Savunma Sanayi: Genel Bir Bakış", Avrasya Sosyal ve Ekonomi Araştırmaları Dergisi (ASEAD), 2018, Cilt: 5, Sayı: 12, 1-19.

${ }^{47}$ Gülay Günlük Şenesen, Türkiye'de Savunma Harcamaları ve Ekonomik Etkileri 1980-2001, 2002, TESEV Yayınları, İstanbul, s. 13. 
Yeni Güvenlik Yaklaşımlarının Savunma Harcamaları Üzerine Etkileri:

G-7, BRICS Ülkeleri İle Türkiye Üzerine Bir Değerlendirme

Tablo 3: Soğuk Savaş Dönemi G-7, BRICS Ülkeleri ile Türkiye'nin Savunma Harcamalarının GSYH İçindeki Payı (\%) 1955-1990 Dönemi ${ }^{48}$

\begin{tabular}{|c|c|c|c|c|c|c|c|c|c|c||}
\hline Ülkeler & $\mathbf{1 9 5 5}$ & $\mathbf{1 9 6 0}$ & $\mathbf{1 9 6 5}$ & $\mathbf{1 9 7 0}$ & $\mathbf{1 9 7 5}$ & $\mathbf{1 9 8 0}$ & $\mathbf{1 9 8 5}$ & $\mathbf{1 9 8 7}$ & $\mathbf{1 9 8 9}$ & $\mathbf{1 9 9 0}$ \\
\hline ABD & 9.7 & 8.6 & 7.2 & 7.7 & 5.4 & 5.0 & 6.1 & 6.1 & 5.5 & 5.3 \\
\hline Almanya & 4.1 & 4.0 & 4.3 & 3.2 & 3.5 & 3.1 & 3.0 & 2.9 & 2.7 & 2.7 \\
\hline İngiltere & 8.1 & 6.3 & 5.8 & 4.6 & 3.5 & 4.5 & 4.8 & 4.2 & 3.6 & 3.6 \\
\hline Fransa & 6.4 & 6.5 & 5.2 & 4.1 & 3.8 & 3.8 & 3.7 & 3.7 & 3.4 & 3.3 \\
\hline İtalya & 3.3 & 2.7 & 2.7 & 2.1 & 2.0 & 1.8 & 1.9 & 2.1 & 2.0 & 1.9 \\
\hline Japonya & 2.1 & 1.1 & 0.9 & 0.8 & 0.9 & 0.9 & 1.0 & 1.0 & 0.9 & 0.9 \\
\hline Kanada & 6.2 & 4.2 & 2.9 & 2.2 & 1.9 & 1.8 & 2.1 & 2.1 & 1.9 & 2.0 \\
\hline Brezilya & $\mathrm{X}$ & 1.9 & 1.9 & 2.3 & 2.0 & 0.9 & 0.8 & 1.0 & 1.4 & 1.7 \\
\hline SSCB & $\mathrm{X}$ & 13.3 & 13.7 & 14 & 13.6 & 14.6 & 12.9 & 12.9 & 11.5 & 11.0 \\
\hline Hindistan & $\mathrm{X}$ & 4.3 & 3.7 & 3.0 & 3.4 & 2.8 & 3.5 & 3.8 & 3.0 & 3.0 \\
\hline Çin & $\mathrm{X}$ & 9.5 & 10.7 & 13.5 & 10.5 & 8.5 & 5.1 & 4.2 & 3.8 & 3.7 \\
\hline G. Afrika & $\mathrm{X}$ & 3.6 & 2.3 & 2.4 & 4.3 & 3.2 & 3.7 & 4.4 & 4.4 & 4.4 \\
\hline Türkiye & $\mathrm{X}$ & 3.5 & 3.6 & 3.3 & 5.1 & 3.9 & 3.5 & 3.3 & 3.1 & 3.5 \\
\hline \hline
\end{tabular}

Soğuk savaş sonrası dönemde Türkiye ile G-7 ve BRICS ülkelerinin savunma harcamalarının GSYH'deki payının 1955-1990 dönemi itibariyle karşılaştırmalı durumu Şekil 1'de gösterilmektedir. Bu dönem boyunca BRICS ülkelerinin en yüksek savunma harcamalarına sahip olduğu görülmektedir. 1970’lere kadar Türkiye'deki savunma

${ }^{48}$ SIPRI, Sipri Military Expenditure Database, (Erişim Tarihi: 04.10.2019); WMEAT, (1964-1990). World Military Expenditures and Arms Transfers. https://www.state.gov/t/avc/rls/rpt/wmeat/ (Erişim Tarihi: 18.09.2019).

293

Güvenlik Stratejileri

Cilt: 16

Say1: 34 
294

Güvenlik Stratejileri

Cilt: 16

Sayı: 34

harcamalarının GSYH içindeki payı G-7 ülkelerinden düşük iken 1970'den sonra daha yüksek olmuştur. Bunun nedenleri yukarıda açıklandığı gibi iç ve dış faktörlere bağlı gelişen olaylardan kaynaklanmaktadır. Ayrıca ifade etmek gerekirse Türkiye'nin savunma harcamalarının GSYH içindeki payı gelişimi itibariyle BRICS ülkeleri ile benzerlik göstermektedir (Şekil 1).

\section{Şekil 1: G-7, BRICS ve Türkiye'nin Savunma Harcamaları Karşılaştırması (GSYH \%)}

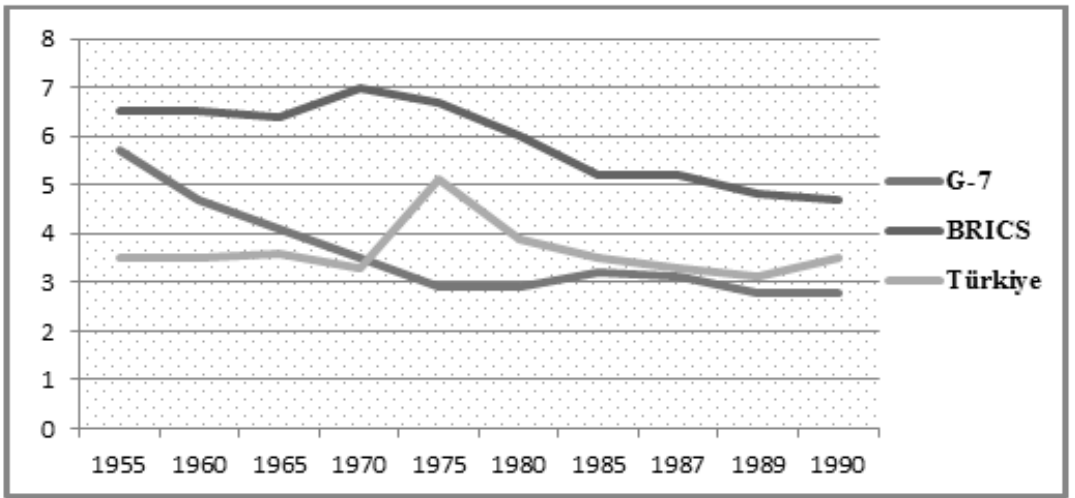

* Tablo 3’teki verilerden yararlanarak yazarlar tarafından oluşturulmuştur.

\subsection{Soğuk Savaş Sonrası Dönemde Savunma Harcamalarının Seyri}

1990'lara gelindiğinde Soğuk Savaş döneminde hakim iki kutuplu sistem yıkılmış, bir süre $\mathrm{ABD}$ 'nin tek süper güç olarak sistemi domine ettiği yeni bir döneme geçilmiştir. ${ }^{49}$ Diğer bir ifadeyle Soğuk Savaş sonrasında askeri politikalarda önemli değişimlerden biri ABD'nin gücü, Berlin duvarının yıkılmasından sonra rakipleri geride bırakacak

${ }^{49}$ Çağdaş Akif Kahraman, a.g.m., s. 108. 
Yeni Güvenlik Yaklaşımlarının Savunma Harcamaları Üzerine Etkileri:

G-7, BRICS Ülkeleri İle Türkiye Üzerine Bir Değerlendirme

şekilde artmıştır. Örneğin 2006 yılında ABD'nin askeri harcamaları, dünya toplam askeri harcamalarının \% 46'sını, Dünya'da askeri harcamalardaki artışın \% 62'sini oluşturmuştur. Bu dengesizlik kutupsuz sistemin özelliğinden kaynaklanmıştır. ${ }^{50}$

Soğuk Savaş sonrası döneminin bitmesiyle birlikte geleneksel güvenlik anlayışının değişmesi daha öncede de belirtildiği üzere ülkelerin çok farklı güvenlik sorunlarıyla uğraşmalarına neden olmuştur. $\mathrm{Bu}$ dönemde ülkelerin güvenliğini tehdit eden başlıca sorunlara örnek olarak; etnik çatışmaları, bölgesel ve ulusal suç örgütlerini, terörizmi, insan kaçakçılı̆̆ını, tehlikeli madde ve silah kaçakçılı̆̆ını, aşırı nüfus artış1 ve çevresel tahribatları göstermek mümkündür. ${ }^{51}$ Soğuk Savaş sonrası Dünya güvenlik yapısında yaşanan bu önemli değişim ülkelerin savunma planlamalarının yeniden yapılanmasına neden olmuştur. Ayrıca bu yeni dönemde tanımlanabilecek bir tehdidin olmaması ve tehditlerin asimetrik hale gelmesi ülkelerin savunma harcamaları planlarının oluşturulmasını da zorlaştırmıştır.

Hem Soğuk Savaşın sona ermesi hem de gelişen dünyanın bazı bölümlerindeki güçlü ekonomik büyüme, savunma bütçelerinin oluşturma meselesini daha da karmaşıklaştırmıştır. ${ }^{52}$

\footnotetext{
${ }^{50}$ Jean- Marc Rickli, Ibid., p. 314.

51 Aleksandar Fatich, "Conventional and Unconventional - 'Hard' and 'Soft' Security: The Distinction”, South-East Europe Review, 2002, Vol: 5, No: 3, 93-98, s. 93.

${ }^{52}$ Karl Skogstad, Ibid., p.323.
}

295

Güvenlik Stratejileri

Cilt: 16

Say1: 34 


\section{6}

Güvenlik Stratejileri Cilt: 16

Sayı: 34
Tablo 4: G-7 Ülkeleri ile Türkiye'nin Savunma Harcamalarının Seyri 1991-2018 (2017 Sabit Fiyatlarıyla, Milyar \$)

\begin{tabular}{||c|c|c|c|c|c|c|c|c||}
\hline Yıllar & ABD & İniltere & Almanya & Fransa & İtalya & Japonya & Kanada & Türkiye \\
\hline 1991 & 504,473 & 51,910 & 58,590 & 59,933 & 28,339 & 41,954 & 15,758 & 9,654 \\
\hline 1992 & 533,052 & 48,486 & 55,722 & 58,047 & 27,524 & 42,585 & 15,584 & 10,154 \\
\hline 1993 & 505,036 & 46,271 & 50,093 & 57,404 & 27,671 & 42,413 & 15,545 & 11,227 \\
\hline 1994 & 476,363 & 44,998 & 46,717 & 57,700 & 26,987 & 42,399 & 15,319 & 10,976 \\
\hline 1995 & 448,560 & 42,205 & 45,949 & 54,843 & 24,647 & 43,101 & 14,438 & 11,276 \\
\hline 1996 & 424,161 & 41,963 & 45,050 & 53,539 & 27,158 & 43,885 & 13,259 & 12,620 \\
\hline 1997 & 421,967 & 40,626 & 43,387 & 53,732 & 28,477 & 44,257 & 12,218 & 13,153 \\
\hline 1998 & 412,438 & 40,864 & 43,537 & 52,304 & 29,419 & 44,307 & 12,641 & 13,782 \\
\hline 1999 & 413,453 & 40,809 & 44,417 & 52,744 & 30,570 & 44,076 & 13,187 & 15,217 \\
\hline 2000 & 429,453 & 41,871 & 43,716 & 52,147 & 32,608 & 44,307 & 12,971 & 14,727 \\
\hline 2001 & 432,941 & 43,565 & 42,998 & 51,987 & 32,073 & 45,083 & 13,314 & 13,500 \\
\hline 2002 & 486,110 & 46,397 & 43,115 & 53,055 & 32,950 & 45,308 & 13,382 & 14,364 \\
\hline 2003 & 553,274 & 49,727 & 42,526 & 54,655 & 33,218 & 45,365 & 13,628 & 13,358 \\
\hline 2004 & 603,024 & 50,306 & 41,223 & 56,147 & 33,326 & 45,184 & 14,144 & 12,414 \\
\hline 2005 & 631,782 & 50,740 & 40,582 & 54,996 & 32,063 & 45,102 & 14,766 & 11,965 \\
\hline 2006 & 641,593 & 51,006 & 39,645 & 55,250 & 31,024 & 44,527 & 15,453 & 12,838 \\
\hline 2007 & 658,438 & 52,587 & 39,679 & 55,462 & 30,139 & 43,948 & 16,847 & 12,343 \\
\hline 2008 & 707,151 & 54,983 & 40,819 & 54,907 & 31,387 & 43,525 & 18,156 & 12,482 \\
\hline 2009 & 763,872 & 56,163 & 42,362 & 58,612 & 30,358 & 44,341 & 18,985 & 13,357 \\
\hline 2010 & 784,835 & 55,407 & 42,824 & 55,932 & 29,491 & 44,496 & 17,148 & 13,087 \\
\hline 2011 & 775,156 & 53,388 & 41,599 & 54,568 & 28,880 & 45,095 & 17,727 & 13,214 \\
\hline 2012 & 731,086 & 51,237 & 42,591 & 53,814 & 26,696 & 44,552 & 16,857 & 13,504 \\
\hline 2013 & 673,102 & 49,199 & 40,133 & 53,679 & 25,674 & 44,363 & 15,582 & 13,838 \\
\hline 2014 & 631,513 & 47,921 & 39,951 & 54,473 & 23,701 & 44,836 & 15,836 & 13,917 \\
\hline 2015 & 616,483 & 46,834 & 41,177 & 56,672 & 22,695 & 45,627 & 18,194 & 14,355 \\
\hline
\end{tabular}

${ }^{53}$ SIPRI, Sipri Military Expenditure Database, (Erişim Tarihi: 04.10.2019). 
Yeni Güvenlik Yaklaşımlarının Savunma Harcamaları Üzerine Etkileri:

G-7, BRICS Ülkeleri İle Türkiye Üzerine Bir Değerlendirme

\begin{tabular}{|l|l|l|l|l|l|l|l|l|}
\hline 2016 & 612,889 & 46,903 & 42,918 & 58,795 & 25,709 & 45,351 & 18,436 & 16,630 \\
\hline 2017 & 605,803 & 46,433 & 45,382 & 60,417 & 26,448 & 45,387 & 21,343 & 17,824 \\
\hline 2018 & 633,565 & 46,883 & 46,192 & 59,542 & 26,082 & 45,362 & 21,352 & 22,088 \\
\hline
\end{tabular}

\section{7}

Güvenlik Stratejileri

Cilt: 16

Say1: 34

Sovyetler Birliğinin dağılmasıyla birlikte dünya savunma harcamalarında ani ve hızlı bir düşüş yaşanmıştır. ${ }^{54}$ Tablo 4'te de görüldüğü üzere 1991 'den 2000 yllına kadar Japonya ve Türkiye'nin dışında ülkelerin savunma harcamalarında ciddi azalışlar meydana gelmiştir. Özellikle ABD söz konusu dönemde savunma harcamalarında $\% 25$ ila \% 30 oranında küçülmeye gitmiş ve askeri güçlerini aynı ölçüde düşürmüştür. ${ }^{55}$

Savunma harcamalarındaki azalma eğilimi 2000'li yıllardan sonra ortadan kalkmış ve harcamalar tekrar ivme kazanmıştır. 2000'den sonra sabit büyüme görülmekle birlikte G-7 ülkeleri ve Türkiye'nin savunma harcamalarında yıllar itibariyle dalgalanmalar görülmektedir (Tablo 4). Nitekim bu dönemde yaşanan savunma harcamalarındaki artışın en önemli nedeni, Dünya savunma harcamalarının yaklaşık yarısını gerçekleştiren ABD'nin doktrin ve stratejisinde yaşanan mevcut değişimlerdir. Özellikle 11 Eylül 2001'de Dünya Ticaret Merkezi'ne yapılan terörist saldırıları sonrasında ABD'nin Afganistan ve Irak'a operasyonlar düzenlemesi savunma harcamalarında büyük bir artışa neden olmuştur.

Türkiye'nin savunma harcamaları G-7 ülkelerine oranla düşük düzeydedir. Ancak Türkiye'nin özellikle 2017 ve 2018 yılı savunma harcamaları verilerine bakıldığında önemli bir artışı olduğu görülmektedir. Bu artışın temel nedeni ise Türkiye'nin sınır güvenliğini sağlamak için gerçekleştirmiş olduğu sınır ötesi askeri operasyonlardan kaynaklanmaktadır.

\footnotetext{
${ }^{54}$ Şennur Sezgin, Savunma Ekonomisi, Nisan Kitapevi, Eskişehir, 2018, s. 105.

55 A. Cohen Eliot, "Defending America in the Twenty-First Century", Foreign Affairs, 2000, Vol: 79, No: 6, 40-56, p. 42.
} 
298

Güvenlik Stratejileri

Cilt: 16

Say1: 34

Tablo 5'te Soğuk Savaş sonrası dönemde BRICS ülkeleri ile Türkiye'nin GSYH içinde savunma harcamaları oranları yer almaktadır. $\mathrm{Bu}$ dönemde özellikle 2000 sonrasında önemli artış olmuştur. Sadece G. Afrika ülkesindeki değişim daha sınırlı olmuştur. Soğuk Savaş döneminde bloklar arası yaşanan silahlanma yarışı, SSCB ekonomisi üzerine ağır bir yük oluşturmuştur. Bu yük Soğuk Savaş sonrası dönemde Rusya tarafindan hafifletilmeye çalışılmıştır. BRICS ülkeleri içinde Çin'e bakıldığında ise Çin'in savunma harcamalarını giderek artırdığ 1 ve en yüksek savunma harcamaları payına sahip ülke konumuna geldiği görülmektedir. ${ }^{56} 2018$ yılı itibariyle Çin, dünyanın ikinci en büyük savunma harcamalarına sahip ülkedir. Çin, ekonomik büyümesi ile birlikte savunma harcamalarını da artırma eğiliminde olan nadir ülkelerden biridir. ${ }^{57}$ Ancak Türkiye'ye bakıldığında ise G. Afrika ülkesi hariç nispi olarak diğer ülkelerden daha düşük savunma harcamasına sahip ülkedir.

\section{Tablo 5: BRICS Ülkeleri ile Türkiye'nin Savunma Harcamalarının Seyri 1991-2018 ${\text { (2017 Sabit Fiyatlarıyla, Milyar } \$)^{58}}^{58}$}

\begin{tabular}{||c|c|c|c|c|c|c||}
\hline Yıllar & Brezilya & Rusya & Hindistan & Çin & G. Afrika & Türkiye \\
\hline 1991 & 1,2124 & - & 18,490 & 22,328 & 3,993 & 9,654 \\
\hline 1992 & 9,45 & 48,655 & 17,671 & 27,126 & 3,438 & 10,154 \\
\hline 1993 & 13,115 & 42,533 & 19,958 & 25,023 & 3,177 & 11,227 \\
\hline 1994 & 15,614 & 40,208 & 20,048 & 24,101 & 3,387 & 10,976 \\
\hline 1995 & 17,555 & 26,455 & 20,648 & 25,015 & 3,013 & 11,276 \\
\hline 1996 & 16,326 & 24,980 & 21,023 & 26,561 & 2,619 & 12,620 \\
\hline 1997 & 16,214 & 27,310 & 23,272 & 28,493 & 2,408 & 13,153 \\
\hline 1998 & 17,428 & 16,241 & 24,280 & 31,211 & 2,133 & 13,782 \\
\hline \hline
\end{tabular}

${ }^{56}$ Seyhan Taş, İbrahim Örnek ve Gül Aksoğan, "Türkiye'de Savunma Harcamaları, Büyüme ve Gelir Eşitsizliği, 1970-2008: Ekonometrik Bir İnceleme”, Gaziantep University Journal of Social Sciences, 2013, Cilt:12, Sayı: 3, 659-682, s. 665.

${ }^{57}$ Nan Tian, vd., "Trends In World Military Expenditure, 2018", SIPRI Fact Sheet, 2019, 1-12, p. 3.

${ }^{58}$ SIPRI, Sipri Military Expenditure Database, (Erişim Tarihi: 17.10.2019). 
Yeni Güvenlik Yaklaşımlarının Savunma Harcamaları Üzerine Etkileri:

G-7, BRICS Ülkeleri İle Türkiye Üzerine Bir Değerlendirme

\begin{tabular}{||l|l|l|l|l|l|l||}
\hline \hline 1999 & 17,853 & 18,036 & 28,217 & 37,971 & 2,044 & 15,217 \\
\hline 2000 & 19,339 & 24,335 & 29,116 & 41,264 & 2,399 & 14,727 \\
\hline 2001 & 22,400 & 26,298 & 30,130 & 49,798 & 2,683 & 13,500 \\
\hline 2002 & 22,699 & 29,133 & 30,037 & 57,835 & 2,940 & 14,364 \\
\hline 2003 & 18,108 & 30,547 & 30,708 & 62,509 & 2,910 & 13,358 \\
\hline 2004 & 18,815 & 31,928 & 35,670 & 69,162 & 3,012 & 12,414 \\
\hline 2005 & 20,358 & 36,284 & 37,961 & 76,558 & 3,344 & 11,965 \\
\hline 2006 & 21,080 & 40,161 & 38,143 & 88,317 & 3,390 & 12,838 \\
\hline 2007 & 22,734 & 43,715 & 38,604 & 98,805 & 3,341 & 12,343 \\
\hline 2008 & 24,184 & 48,033 & 43,786 & 108,187 & 3,317 & 12,482 \\
\hline 2009 & 26,369 & 50,396 & 51,553 & 131,063 & 3,468 & 13,357 \\
\hline 2010 & 29,283 & 51,420 & 51,759 & 137,890 & 3,357 & 13,087 \\
\hline 2011 & 28,364 & 54,877 & 52,261 & 148,656 & 3,477 & 13,214 \\
\hline 2012 & 28,910 & 63,584 & 52,075 & 161,441 & 3,634 & 13,504 \\
\hline 2013 & 29,067 & 66,682 & 51,691 & 176,476 & 3,706 & 13,838 \\
\hline 2014 & 29,648 & 71,467 & 54,214 & 191,627 & 3,710 & 13,917 \\
\hline 2015 & 28,961 & 77,023 & 54,729 & 204,202 & 3,741 & 14,355 \\
\hline 2016 & 27,491 & 82,576 & 60,311 & 215,718 & 3,679 & 16,630 \\
\hline 2017 & 29,283 & 66,527 & 64,559 & 227,829 & 3,639 & 17,824 \\
\hline 2018 & 30,769 & 64,193 & 66,578 & 239,223 & 3,449 & 22,088 \\
\hline \hline
\end{tabular}

\section{9}

Güvenlik

Stratejileri

Cilt: 16

Say1: 34

SIPRI (2019)'a göre 2018 y1lında dünya savunma harcamalar1 1.822 milyar dolar olarak tahmin edilmiştir. Bu da global GSYH'nin 2,1'ine ve kişi başına 239 dolara denk gelmektedir. 2018 yılında en çok savunma harcamasına sahip ülkelerin başında ABD, Çin, Sudi Arabistan, Hindistan ve Fransa gelmektedir(Tablo 4-5).

Soğuk Savaş sonrası savunma harcamaları en çok artan ülkeler ABD ve Çin'dir (Tablo 4-5). ABD 2018 y1lında savunmaya 633 milyar dolar harcamıştır. $\mathrm{Bu}$ tutar dünyadaki toplam askeri harcamaların \% 36'sını oluşturmaktadır. ABD'den sonra gelen Çin, 2018 yılında 239 milyar dolar savunmaya harcamıştır. Dünya'da savunma harcamaları bakımından dördüncü sırada yer alan Hindistan savunmaya 66.5 milyar dolar ayırmıştır. 2006'dan beri en çok savunma harcaması yapan ilk beş ülkeden biri olan Rusya ise savunma harcamalarını \% 22 azaltarak savunmasına 64.1 milyar dolar ayırdığı görülmektedir. 2018 yılı itibariyle Türkiye'nin savunma harcaması ise 22.0 milyar dolar olmuştur. Coğrafi olarak birçok tehdidin 
300

Güvenlik Stratejileri

Cilt: 16

Sayı: 34 çok yakınında olan Türkiye için savunma alanında yüksek harcamalar kaçınılmazdır.

Tablo 6'da 1995-2018 yılları arası G-7, BRICS ülkeleri ile Türkiye'nin GSYH içinde savunma harcamalarının payı yer almaktadır. Tablo 6'ya bakıldığında Soğuk Savaş sonrası dönemde ülkelerin GSYH içinde savunma harcamalarının payı yıllar arasında dalgalanmalar olmakla birlikte genel olarak düştüğü görülmektedir. Örneğin ABD 1995 yılında GSYH içinde savunmaya 3,6'llk bir pay ayırırken 2000 yılına gelindiğinde bu pay azalarak 2,9 olmuştur. Ancak sonraki yıllarda uluslararası terör saldırılarıyla artan güvenlik kaygıları nedeniyle $A B D$ tekrar savunma harcamalarını artırmış ancak 2018'de 3,2'ye düşürmüştür. Soğuk Savaş öncesinde olduğu gibi Soğuk Savaş sonrasında da savunma harcamalarının GSYH içindeki payı en yüksek olan ülke 2008-2012 yılları haricinde Rusya'dır. Rusya'nın hemen ardından ABD gelmektedir. Çin'de savunma harcamalarının GSYH içindeki payında 1985'ten başlayan düşmenin Soğuk Savaş sonrası dönemde de devam ettiği görülmektedir. Türkiye'de de savunma harcamalarının GSYH içindeki payı bu dönemde genel olarak düşmüştür.

Tablo 6: Soğuk Savaş Sonrası Dönemde G-7, BRICS Ülkeleri ile Türkiye'nin Savunma Harcamalarının GSYH İçindeki Payı $(\%, 1995-2018 \text { Dönemi })^{59}$

\begin{tabular}{|c|c|c|c|c|c|c|c|c|c|c|c|c|c|}
\hline Yillar & 党 & 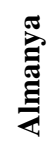 & 窇 & 总 & $\stackrel{\frac{\pi}{\pi}}{\stackrel{\pi}{\leftrightarrows}}$ & 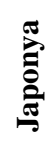 & 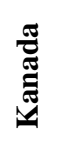 & 苞 & 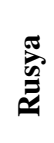 & 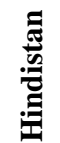 & $\Xi$ & $\underbrace{\frac{\pi}{3}}_{0}$ & : \\
\hline 1995 & 3,6 & 1,6 & 2,6 & 3,0 & 1,5 & 0,9 & 1,6 & 1,9 & 4,1 & 2,6 & 1,7 & 2,1 & 3,9 \\
\hline 1996 & 3,4 & 1,6 & 2,5 & 2,9 & 1,6 & 0,9 & 1,4 & 1,7 & 4, & 2,5 & 1,7 & 1,8 & 4,1 \\
\hline 1997 & 3,2 & 1,5 & 2,3 & 2,8 & 1,6 & 0,9 & 1,2 & 1,6 & 4, & 2,6 & 1,7 & 1,6 & 4,1 \\
\hline 1998 & 3,0 & 1,5 & 2,3 & 2,7 & 1,6 & 0,9 & 1,3 & 1,7 & 3,0 & 2,7 & 1,7 & 1,3 & 3,2 \\
\hline
\end{tabular}

${ }^{59}$ SIPRI, Sipri Military Expenditure Database, (Erişim Tarihi: 25.10.2019). 
Yeni Güvenlik Yaklaşımlarının Savunma Harcamaları Üzerine Etkileri: G-7, BRICS Ülkeleri İle Türkiye Üzerine Bir Değerlendirme

\begin{tabular}{|l|l|l|l|l|l|l|l|l|l|l|l|l|l|}
\hline 1999 & 2,9 & 1,5 & 2,2 & 2,6 & 1,7 & 0,9 & 1,2 & 1,6 & 3,3 & 3,0 & 1,9 & 1,4 & 3,9 \\
\hline 2000 & 2,9 & 1,4 & 2,1 & 2,5 & 1,7 & 0,9 & 1,1 & 1,7 & 3,6 & 2,9 & 1,9 & 1,4 & 3,7 \\
\hline 2001 & 2,9 & 1,4 & 2,2 & 2,4 & 1,7 & 0,9 & 1,1 & 2,0 & 3,8 & 2,9 & 2,1 & 1,5 & 3,6 \\
\hline 2002 & 3,2 & 1,4 & 2,2 & 2,4 & 1,7 & 1,0 & 1,1 & 1,9 & 4,1 & 2,8 & 2,2 & 1,5 & 3,8 \\
\hline 2003 & 3,6 & 1,4 & 2,3 & 2,5 & 1,7 & 1,0 & 1,1 & 1,5 & 3,9 & 2,7 & 2,1 & 1,5 & 3,3 \\
\hline 2004 & 3,8 & 1,3 & 2,3 & 2,4 & 1,7 & 0,9 & 1,1 & 1,5 & 3,5 & 2,8 & 2,1 & 1,4 & 2,7 \\
\hline 2005 & 3,9 & 1,3 & 2,2 & 2,4 & 1,6 & 0,9 & 1,1 & 1,5 & 3,6 & 2,8 & 2,0 & 1,4 & 2,4 \\
\hline 2006 & 3,8 & 1,3 & 2,1 & 2,3 & 1,5 & 0,9 & 1,1 & 1,5 & 3,5 & 2,5 & 1,9 & 1,3 & 2,4 \\
\hline 2007 & 3,9 & 1,2 & 2,2 & 2,3 & 1,5 & 0,9 & 1,2 & 1,5 & 3,4 & 2,3 & 1,9 & 1,2 & 2,3 \\
\hline 2008 & 4,2 & 1,4 & 2,3 & 2,3 & 1,5 & 0,9 & 1,2 & 1,4 & 3,3 & 2,6 & 2,1 & 1,1 & 2,2 \\
\hline 2009 & 4,6 & 1,4 & 2,4 & 2,5 & 1,6 & 1,0 & 1,4 & 1,5 & 4,1 & 2,9 & 1,9 & 1,2 & 2,5 \\
\hline 2010 & 4,7 & 1,4 & 2,4 & 2,3 & 1,5 & 1,0 & 1,2 & 1,5 & 3,8 & 2,7 & 1,9 & 1,1 & 2,3 \\
\hline 2011 & 4,6 & 1,3 & 2,3 & 2,3 & 1,5 & 1,0 & 1,2 & 1,4 & 3,5 & 2,7 & 1,8 & 1,1 & 2,1 \\
\hline 2012 & 4,2 & 1,3 & 2,2 & 2,2 & 1,4 & 1,0 & 1,1 & 1,4 & 3,8 & 2,5 & 1,8 & 1,1 & 2,1 \\
\hline 2013 & 3,8 & 1,2 & 2,1 & 2,2 & 1,4 & 1,0 & 1,0 & 1,3 & 3,9 & 2,5 & 1,9 & 1,1 & 2,0 \\
\hline 2014 & 3,8 & 1,2 & 1,9 & 2,2 & 1,3 & 1,0 & 1,0 & 1,3 & 4,1 & 2,5 & 1,9 & 1,1 & 1,9 \\
\hline 2015 & 3,3 & 1,2 & 1,9 & 2,3 & 1,2 & 1,0 & 1,2 & 1,4 & 4,9 & 2,4 & 1,9 & 1,1 & 1,8 \\
\hline 2016 & 3,2 & 1,2 & 1,8 & 2,3 & 1,3 & 0,9 & 1,2 & 1,4 & 5,5 & 2,5 & 1,9 & 1,1 & 2,1 \\
\hline 2017 & 3,1 & 1,2 & 1,8 & 2,3 & 1,4 & 0,9 & 1,3 & 1,4 & 4,3 & 2,5 & 1,9 & 1,0 & 2,1 \\
\hline 2018 & 3,2 & 1,2 & 1,8 & 2,3 & 1,3 & 0,9 & 1,3 & 1,5 & 3,9 & 2,4 & 1,9 & 1,0 & 2,5 \\
\hline
\end{tabular}

\section{1}

Güvenlik Stratejileri

Cilt: 16

Say1: 34

Türkiye, G-7 ve BRICS ülkeleri karşılaştırması Şekil 2'de gösterilmektedir. Ülke grupları karşılaştırıldığında BRICS ülkelerinin GSYH içinde savunmaya ayırdıkları payların G-7 ülkelerinden daha fazla olduğu görülmektedir. BRICS ülkelerinin GSYH içinde savunma harcamaları paylarının G-7 ülkelerinden fazla olması güvenlik kaygılarından ziyade ekonomik temelli ve kısmen de uluslararasında stratejik konumlarının güçlendirilmesi isteğine dayalı olduğunu ifade etmek mümkündür. 21. yüzyılda BRICS ülkelerinin yükselen bir güç haline gelmesi ve milli gelirlerindeki hızlı artışlar savunma harcamalarına da yansımıştır. 
302

Güvenlik Stratejileri

Cilt: 16

Sayı: 34

Şekil 2: Soğuk Savaş Sonrası G-7, BRICS ve Türkiye'nin Savunma Harcamaları Karşılaştırması (GSYH \%)

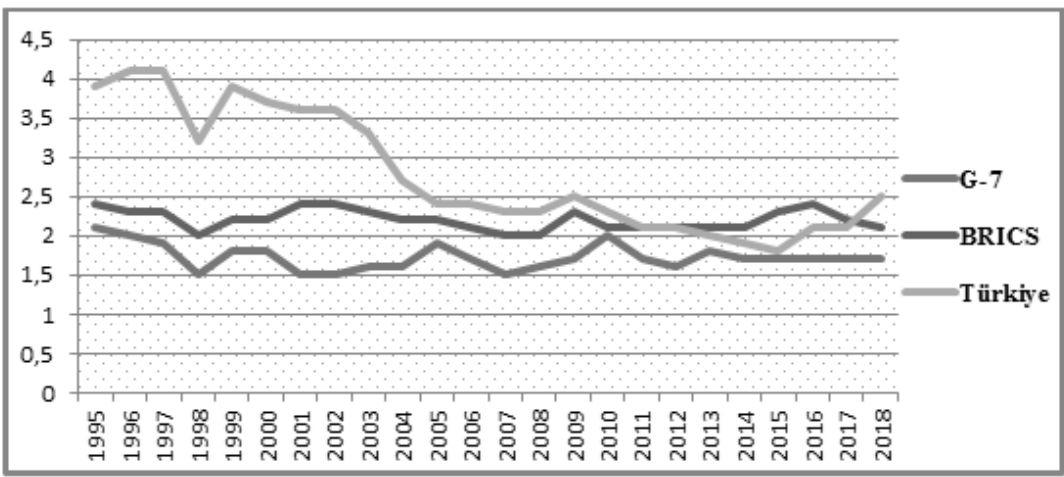

*SIPRI verilerinden yararlanarak yazarlar tarafindan oluşturulmuştur.

Soğuk Savaş öncesi dönemle karşılaştırıldığında savunma harcamalarının GSYH içindeki payı açısından şu değişiklikler olmuştur (Şekil 1 ve 2):

- Soğuk Savaş öncesi dönemde savunma harcamalarının GSYH içindeki payı tüm dönem boyunca en yüksek ülke grupları BRICS ülkeleri olmuştur. İkinci sırada 1970 yılına kadar G-7 ülkeleri yer alırken, bu ülke grubu 1970'den sonra Türkiye'nin arkasından üçüncü sıraya düşmüştür.

- Soğuk Savaş sonrası dönemde sıralama tamamen değişmiştir. 2012 yılına kadar Türkiye birinci sirada yer alırken bu yıldan sonra 2018'e kadar ikinci sırada yer almıştır. 2017'de tekrar ilk sıraya yükselmiştir. BRICS ülkeleri 2012'den sonra 2017'ye kadar kısa dönem ilk sırada yer almış sonra tekrar ikinci sıraya düşmüştür. G-7 ülkeleri ise Türkiye ve BRICS ülkelerini takip etmiştir.

$\mathrm{Bu}$ değişimler başta Türkiye olmak üzere gelişmekte olan ülkelerin savunma harcamalarının GSYH'ya katkısının özellikle savunma sanayinin gelişmesiyle birlikte daha fazla katkı sağladığını göstermektedir. 
Yeni Güvenlik Yaklaşımlarının Savunma Harcamaları Üzerine Etkileri:

G-7, BRICS Ülkeleri İle Türkiye Üzerine Bir Değerlendirme

\section{Sonuç ve Değerlendirme}

Soğuk Savaş Döneminde hakim olan geleneksel güvenlik anlayışı, askeri konulara önem vermekte ve devleti temel aktör olarak görmekteydi. Ancak Soğuk Savaşın sona ermesi ile birlikte güvenlik anlayışında da değişim yaşanmış, geleneksel güvenlik anlayışı sorgulanır hale gelmiştir. Bu yeni dönemde güvenliğin ekonomik, politik, sosyal, askeri ve çevresel boyutlarını ele alan "Yeni Güvenlik Yaklaşımları" olarak da ifade edilen çok boyutlu bir güvenlik anlayışına geçilmiştir. Dünya güvenlik anlayışında yaşanan bu önemli değişim ülkelerin savunma planlamalarının yeniden yapılanmasına da neden olduğu saptanmıştır. Örneğin ülkeler, Soğuk Savaş döneminde "Tehdide Dayalı" bir savunma planlaması yaparlarken Soğuk Savaş sonrası dönemde "Yeteneğe Dayalı" ve "Yetenek Tabanlı" bir savunma planlaması yaptıkları tespit edilmiştir. G-7, BRICS ülkeleri ile Türkiye'nin savunma planlamalarına bakıldığında ise Kopenhag Okulu'nun sektörel güvenlik kapsamındaki tüm faktörleri hesaba katan "Yetenek Tabanlı Planlama" anlayışı kapsamında hazırlandığ 1 görülmüştür. Söz konusu ülkelerin savunma planlamalarını "Yetenek Tabanlı Planlama" esasına göre hazırlamaları, savunma harcamalarının optimal düzeyde belirlenmesine büyük katk1 sağlandığı gözlemlenmiştir.

Savunma harcamaları, standart tanımı bulunmayan bir kavramdır. Bunun temel nedeni ise savunma harcamaları kalemlerinin ülkeden ülkeye farklılık göstermesidir. Bundan dolayı Soğuk Savaş sonrası dönemde güvenlik kavramı her ne kadar genişleyip derinleşse de savunma harcamalarının salt bu nedenle arttığını söylemek mümkün değildir. Çünkü güvenlik kapsamına alınan bazı konuların (toplumsal güvenlik, ekonomik güvenlik, insan güvenliği, çevresel güvenlik, cinsiyet güvenliği vb.) savunma bütçesinden ziyade farklı bütçe kalemlerine alınmakta ve giderler bu bütçelerden gerçekleştirilmektedir. Güvenliğin kavramsal olarak genişlediği Soğuk Savaş sonrası dönemde G-7, BRICS ülkeleri ile Türkiye'nin savunma harcamaları düzeyi bu savı doğrular niteliktedir. G-7, BRICS ülkeleri ile Türkiye'nin savunma harcamalarına bakıldığında ABD'nin her dönem zirvedeki yerini koruduğunu ancak Çin'in ise yükselen bir güç ile ABD'yi izlediği görülmüştür. 
304

Güvenlik Stratejileri

Cilt: 16

Sayı: 34

G-7, BRICS ülkeleri ile Türkiye'nin savunma harcamalarının GSYH içindeki payları özellikle Soğuk Savaş Döneminde Türkiye dışında önemli oranda düşmüştür. Soğuk Savaş sonrası dönemde ise düşük oranda da olsa ülkelerin savunma harcamalarındaki düşüşlerin devam ettiği görülmüştür. Soğuk Savaş öncesi dönemde savunma harcamalarının GSYH içindeki payı tüm dönem boyunca en yüksek ülke grupları BRICS ülkeleri ikinci sırada G-7 ülkeleri ve Türkiye ise üçüncü sırada yer almışken, Soğuk Savaş sonrasında sıralama değişmiştir. 2012-2017 yılları haricinde ilk sırada Türkiye yer alırken onu BRICS ülkeleri ve G-7 ülkeleri izlemiştir. Analiz sonuçları bağlamında denilebilir ki savunma harcamaları düzeyi, güvenliğin kavramsal olarak genişlemesinin yanı sıra risk ve tehditlerin belirginleşmesi, tehditlerin asimetrik hale gelmesi, ülkelerin coğrafi konumları, komşu ülkelerin savunma harcamaları düzeyi ve yaşanan diğer dışsal problemlerden kaynaklı arttığını söylemek mümkündür. Yapılan analizler ve elde edilen bulguların ilgili alanda yapılan çalışmaları da desteklemektedir.

\section{Summary}

The required for security has been among the basic needs since the existence of humanity. Such an important need, which dates back as far as human history, is being fulfilled by states today as it used to be. While there are many reasons why the need for security is fulfilled by the states, the main reason is that the survival of the state and security are of full public goods and services. In other words, security is a type of service that has an indivisible feature in which no individual can be excluded from its benefits and everyone benefits at the same level. In this context, states have to allocate humanitarian and material resources to combat actual or potential threats to their security.

There has been a serious change and transformation in security studies with the beginning of the globalization process and the end of the Cold War. From the prevailing traditional security paradigm of the Cold War era to a multidimensional security understanding that addresses the economic, political, social, military and environmental dimensions of security. In this context, it is of great importance to investigate the impact 
Yeni Güvenlik Yaklaşımlarının Savunma Harcamaları Üzerine Etkileri:

G-7, BRICS Ülkeleri İle Türkiye Üzerine Bir Değerlendirme

of this multidimensional change in security understanding on the state's defense expenditures and the level of this effect.

In this study, the defense expenditures of G-7 (USA, Germany, France, UK, Italy, Japan, Canada), BRICS (Brazil, Russia, India, China, South Africa) and Turkey, which are among the top 15 sources of defense in the world in line with the pre-and post-Cold War security approaches, were be analyzed. In this context, after the conceptual framework was first drawn, the change and transformation in "the New Approach of Security" in the post-Cold War period was explained. Subsequently, Social Constructors, Critical Approaches, the Welsh School and the Copenhagen School, which had an important role in the formation of the theoretical foundations of the new approach of security, were described. In the second part of the study, the literature on the subject is given. In the third chapter, as well as during the Cold War and post-Cold War era in the context of security, G-7, BRICS countries and Turkey's defense spending share of GDP were analyzed the correlation between security and defense spending is presented in detail.

\section{KAYNAKÇA \\ Kitaplar}

AKÇADAĞ ALAGÖZ Emine, “Kuzeydoğu Asya'nın Değişen Güvenlik Ortamı”, Hasret Çomak, Caner Sancaktar ve Sertif Demir, (ed.), Uluslararası Güvenlik Yeni Politikalar, Stratejiler ve Yaklaşımlar, Beta Yayınevi, İstanbul, 2016.

ARI Tayyar, Uluslararası İlişsiler ve Dış Politika, Alfa Akademi Yayınları, Bursa, 2017.

BİNGÖL Oktay, "Yeni Güvenlik Yaklaşımları ve 21. Yüzyıl Güvenlik Sorunları", Hasret Çomak, Caner Sancaktar ve Sertif Demir, (ed.), Uluslararası Güvenlik Yeni Politikalar, Stratejiler ve Yaklaşımlar, Beta Yayınevi, İstanbul, 2016.

BUZAN Barry ve Ole Waever, Regions and Powers, Cambridge University Press, Cambridge, 2003.

BUZAN Barry, Ole Wæver ve Jaap De Wilde, Security: A New Framework for Analysis, Lynne Rienner Publishers, Londra, 1998.

BUZAN Barry, People, States, and Fear: The National Security Problem in International Relations, Brighton 1983.

DEDEOĞLU Beril, Uluslararası Güvenlik ve Strateji, Derin Yayınları, İstanbul, 2008. 


\section{Servet TAŞDELEN - Filiz GİRAY}

\section{6}

Güvenlik Stratejileri

Cilt: 16

Sayı: 34

EZEANI Emmanuel O. ve Ezeibe Christian C., "Defence Expenditure and National Security in Nigeria", Ozoemenam Mbachu ve Ahmed Aliyu Sokoto, (ed.), Nigerian Defence And Securty: Policies and Strategies, Medusa Academic Publishers Limited, Kaduna, 2011.

SEZGIN Şennur, Savunma Ekonomisi, Nisan Kitapevi, Eskişehir, 2018.

ŞENESEN Gülay Günlük, Türkiye'de Savunma Harcamaları ve Ekonomik Etkileri 1980-2001, TESEV Yayınları, İstanbul, 2002.

TİAN Nan, vd., "Trends In World Military Expenditure, 2018”, SIPRI Fact Sheet, 2019.

WENT Alexander, Social Theory of International Politics, Cambridge University Press, Cambridge, 1992.

\section{Makaleler}

AÇIKMEŞE-AKGÜL Sinem, "Alg1 mı Söylem mi? Kopenhag Okulu ve Yeni-Klasik Gerçekçilikte Güvenlik Tehditleri”, Uluslararası İlişkiler, 2011, Cilt: 8, Sayı: 30, 4373, ss. 57-59.

BAKAN Selahaddin ve Sonay Şahin, "Uluslararası Güvenlik Yaklașımlarının Tarihsel Dönüşümü ve Yeni Tehditler", The Journal of International Lingual, Social and Educational Science, 2018, Cilt: 4, Say1: 2, ss. 135-152.

BALDWIN David A., "The Concept Of Security", Review Of International Studies, 1997, Vol: 23, ss. 5-26.

BAYLİS John, "Uluslararası İlișkilerde Güvenlik Kavramı", Uluslararası İlișkiler, 2008, Cilt: 5, Say1: 18, 69-87, ss. 80-81

BAYSAL Başar ve Çağla Lüleci, "Kopenhag Okulu ve Güvenlikleştirme Teorisi", Güvenlik Stratejileri, 2011, ss. 22: 61-96.

BENOİT Emile, Harold Lubell ve Sylvia Schuman, "World Defense Expenditures", Journal of Peace Research, 1966, Vol: 3, No: 2, ss. 97-113.

BİLGIN Pınar, "Güvenlik Çalışmalarında Yeni Açılımlar: Yeni Güvenlik Çalışmaları", Stratejik Araştırmalar, 2010, Cilt: 8, Sayı: 14.

BİRDISSLI Fikret, "Eleştirel Güvenlik Çalışmaları Kapsamında Frankfurt Okulu ve Soğuk Savaş Sonrası Güvenlik Sorunlarına Eleştirel Bir Yaklaşım: Galler Ekolü”, Güvenlik Stratejileri, 2014, Cilt: 10, Say1: 20, 229-256, ss. 243-244.

BOOTH Keen, "Security and Emancipation, Review of International Studies", Cambridge University Press, 1991, Cilt: 17, Say1: 4, ss. 313-326.

BRAUCH Hans Günter, "Güvenliğin Yeniden Kavramsallaştırılması: Barış, Güvenlik, Kalkınma ve Çevre Kavramsal Dörtlüsü”, Uluslararası İlişkiler, 2008, Cilt:5, Sayı:18, ss. 1-47.

BROMUND Ted R., "Demystifying Defense: Exposing Myths about US Military Expenditures", Harvard International Review, 2009, Vol: 31, No: 1, ss. 36-40,

CUSACK Thomas R. ve Michael Don Ward, "Military Spending İn The United States, Soviet Union, And The People's Republic Of China", Journal of Conflict Resolution, 1981, Vol: 25, No: 3, ss. 429-469.

ELIOT A. Cohen, "Defending America in the Twenty-First Century", Foreign Affairs, 2000, Vol: 79, No: 6, ss. 40-56. 
Yeni Güvenlik Yaklaşımlarının Savunma Harcamaları Üzerine Etkileri: G-7, BRICS Ülkeleri İle Türkiye Üzerine Bir Değerlendirme

EMEKLIER Bilgehan, "Uluslararası İlişkiler Disiplininde Epistemolojik Paradigma Tartışmaları: Postpozitivist Kuramlar". Bilge Strateji, 2011, Cilt: 2, Sayı: 4, ss. 139-184. FATICH Aleksandar, "Conventional and Unconventional - 'Hard' and 'Soft' Security: The Distinction”, South-East Europe Review, 2002, Vol: 5, No: 3, ss. 93-98.

HUYSMANS Jef, "Revisiting Copenhagen: Or, On the Creative Development of a Security Studies Agenda in Europe", European Journal of International Relations, 1998, Vol: 4, No: 4, 479-505, ss. 479-480.

KAHRAMAN Çağdaş Akif, "Tarihsel Süreçte Savunma Planlaması Yaklaşımları İle Savunma Tedarik Sistemleri Arasındaki İlişki”, Kara Harp Okulu Bilim Dergisi, 2016, Cilt: 26, Sayı: 2, ss. 101-126.

KOLLIAS Christos ve Suzanna Maria Paleologou, "Domestic Political And External Security Determinants Of The Demand For Greek Military Expenditure", Defence and Peace Economics, 2003, Vol: 14, No: 6, ss. 437-445.

KRTALIĆ Sandra ve Aleksandar Major, "Military Expenditures in the Maelstrom of the Globalized World" Economic Research-Ekonomska Istraživanja, 2010, Vol: 23, No: 2, ss. 142-161.

PAMP Oliver ve Paul W. Thurner, "Trading Arms and The Demand For Military Expenditures: Empirical Explorations Using New SIPRI-Data", Defence and Peace Economics, Vol: 28, No: 4, ss. 457-472.

RİCKLİ Jean- Marc, "European Small States' Military Policies After the Cold War: From Territorial To Niche Strategies", Cambridge Review Of International Affairs, 2008, Vol: 21, No: 3, ss. 307-325.

SANCAK Kadir, "Güvenlik Kavramı Etrafındaki Tartışmalar ve Uluslararası Güvenliğin Dönüşümü”, Sosyal Bilimler Dergisi, 2013, Say1: 6, ss. 123-134.

SEZGIN Şennur ve Selami Sezgin, "Dünya'da ve Türkiye'de Savunma Sanayi: Genel Bir Bakış", Avrasya Sosyal ve Ekonomi Araştırmaları Dergisi (ASEAD), 2018, Cilt: 5, Say1: 12, ss. 1-19.

SKOGSTAD Karl, "Defence Budgets In the Post-Cold War Era: A Spatial Econometrics Approach", Defence and Peace Economics, 2016, Vol: 27, No: 3, ss. 323-352.

SOPO Elina, "Securitising Culture During the Cold War: The Geopolitical Aspect of Culture in European Discussions, 1949-1974", The International History Review, 2020, Vol: 42, No: 2, ss. 391-409.

TAŞ Seyhan, İbrahim Örnek ve Gül Aksoğan, "Türkiye'de Savunma Harcamaları, Büyüme ve Gelir Eşitsizliği, 1970-2008: Ekonometrik Bir İnceleme", Gaziantep University Journal of Social Sciences, 2013, Cilt:12, Say1: 3, ss. 659-682.

TOPÇU Mustafa Kemal, "Savunma Planlamasının Ekonomiye Etkileri ve Savunma Bütçeleri”, Savunma Bilimleri Dergisi, 2010, Cilt: 9, Say1: 1, ss. 75-96.

WASZKIEWICZ Grzegorz, "Drivers Of Greek And Turkish Defense Spending", International Journal of Management and Economics, 2016, Vol: 51, No: 1, ss. 33-46. WENT, Alexander, "Collective Identity Formation and the International State", American Political Science Review, 1994, Vol: 88, No: 2, ss. 384-396.

WENDT Alexander, "Anarchy is What States Make of It: The Social Construction of Power Politics”, International Organisation, 1992, Vol: 46, No: 2, 391-425. 


\section{Servet TAŞDELEN - Filiz GİRAY}

308

Güvenlik

Stratejileri

Cilt: 16

Sayı: 34

WOLFERS Arnold, "National Security as an Ambiguous Symbol", Political Science Quarterly, 1952, Vol: 67, No:: 4, ss. 481-502.

WYNER Brittani ve Ligun Xie, "Modeling China's Military Expenditures as an Action-Reaction Process: A Preliminary Study", Journal of Chinese Political Science, 1997, Vol: 3, No: 2, ss. 47-70.

ZAYIF Vedat ve Memed Erkenekli, "Kültürel Değerlerin Savunma Harcamalarına Yansıması: NATO Ülkeleri Arasında Bir Uygulama", Savunma Bilimleri Dergisi, Cilt: 14, Say1: 2, ss. 1-43.

\section{Internet}

WEAWER Ole, "Aberystyth, Paris, Copenhagen: New Schools in Security Theory and Their Origins Between Core and Periphery", http://www.scribd.com/doc/40010349/ Ole-Waever-Aberystwyth-Paris-enNew-Schools-in-Security-Theory-and-TheirOrigins-Between-Core-andPeriphery. (Erişim Tarihi: 11.10.2019).

SIPRI, Sipri Military Expenditure Database, (Erişim Tarihi: 25.10.2019). SIPRI, Sipri Military Expenditure Database, (Erişim Tarihi: 04.10.2019). WMEAT, World Military Expenditures and Arms Transfers, 1964-1990, https://www.state.gov/t/avc/rls/rpt/wmeat/_ (Erişim Tarihi: 18.09.2019). 